\title{
ISOLATION, CULTIVATION AND \\ PHENOTYPIZATION OF HUMAN CORNEAL STROMA AND ENDOTHELIAL CELLS- \\ IMPLICATIONS FOR TISSUE ENGINEERING AND TRANSPLANTATION
}

Richárd Nagymihály, M.Sc.

Supervised by:

Prof. Dr. Goran Petrovski

$\mathrm{MD}, \mathrm{PhD}$, med. Habil

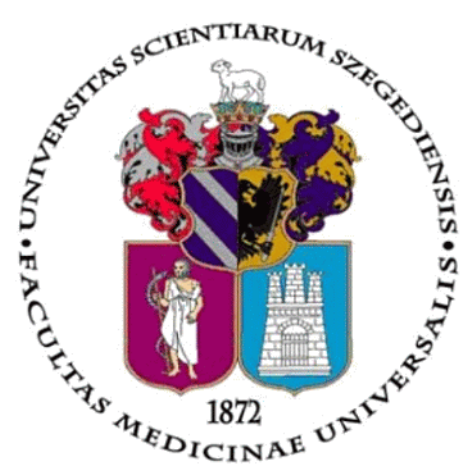

UNIVERSITY OF SZEGED

DOCTORAL SCHOOL OF CLINICAL MEDICINE

DEPARTMENT OF OPHTALMOLOGY

SZEGED, 2017 


\section{Scientific publications and articles:}

Publications related to the thesis:

I. Cultivation and characterisation of the surface markers and carbohydrate profile of human corneal endothelial cells.

Nagymihály R, Veréb Z, Albert R, Sidney L, Dua H, Hopkinson A, Petrovski G

Clin Exp Ophthalmol. 2017 July; Vol 45, Issue 5: 509-19. doi:10.1111/ceo.12903.

[Epub 2017 Feb 14.]

IF: 3.0

II. Effect of isolation technique and location on the phenotype of human corneal stroma-derived cells

Richard Nagymihaly, Zoltán Veréb, Andrea Facskó, Morten C. Moe, Goran Petrovski

Stem Cells International, Special issue: "The Stem Cell Niche: Interactions between Stem Cells and Their Environment”, 2017 Aug

IF: 3.54

\section{Other publications:}

I. Cultivation and characterization of pterygium as an ex vivo study model for disease and therapy

Josifovska N, Szabó DJ, Nagymihály R, Veréb Z, Facskó A, Eriksen, Moe MC, Petrovski G

Cont Lens Anterior Eye. 2017 May 24. pii: S1367-0484(16)30117-5. doi: 10.1016/j.clae.2017.04.002. [Epub ahead of print]

IF: 1.831 
II. Long-Term Cultures of Human Cornea Limbal Explants Form 3D Structures Ex Vivo - Implications for Tissue Engineering and Clinical Applications.

Szabó DJ, Noer A, Nagymihály R, Josifovska N, Andjelic S, Veréb Z, Facskó A, Moe MC, Petrovski G.

PLoS One. 2015 Nov 18;10(11): e0143053. doi: 10.1371/journal.pone.0143053.

IF: 3.54

III. Cell death, clearance and inflammation: molecular crossroads and gene polymorphisms in the pathogenesis of age-related macular degeneration

Dóra Júlia Szabó, Marika Tóth, Zoltán Doró, Richárd Nagymihály, Natasha Josifovska, Andrea Facskó, Goran Petrovski

Journal of Biochemical and Pharmacological Research 2:(3) pp. 132-143. (2014)

IV. Measurement of thrombin in different matrices: whole blood, platelet-rich and platelet-poor plasma using fluorogenic substrate ZGGR-AMC

Mitchell JA, Nagymihaly R, Uhrinyi OM, Hársfalvi J.

Acta Haematol. 2013;130(3):150-2. doi: 10.1159/000347179. Epub 2013 May 9. PubMed PMID: 23689593

IF: 1.27

IF of publications related to the thesis: 6.54

IF of all publications: 13.181 


\section{Contents}

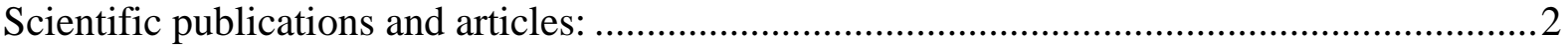

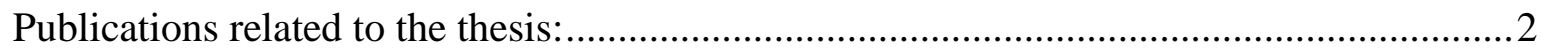

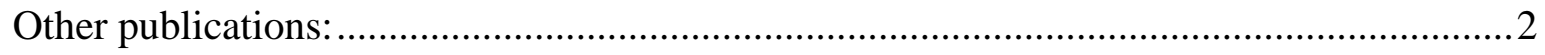

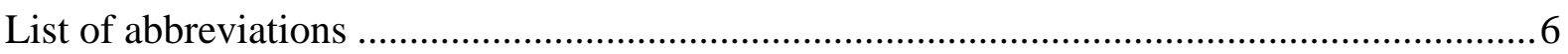

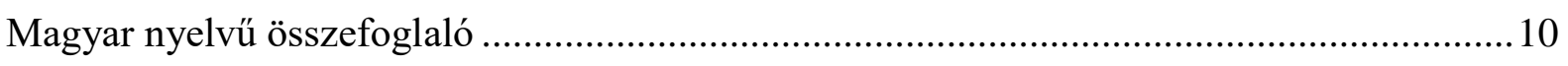

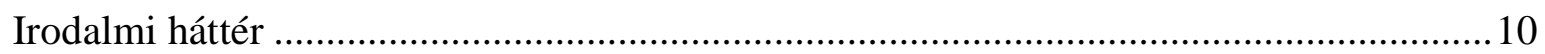

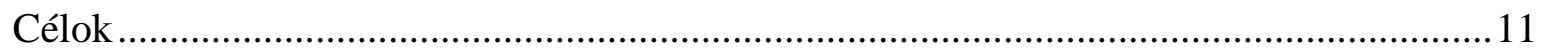

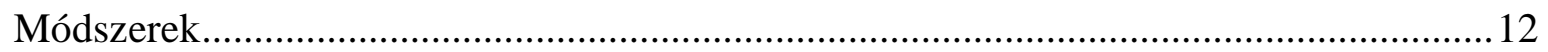

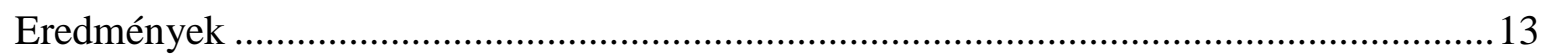

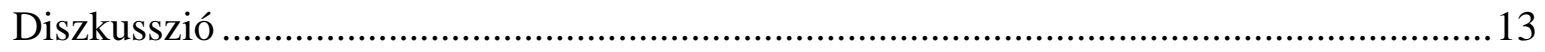

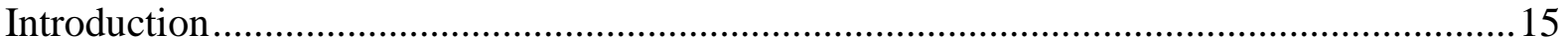

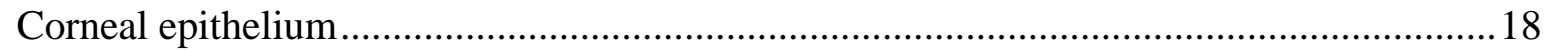

Corneal stroma

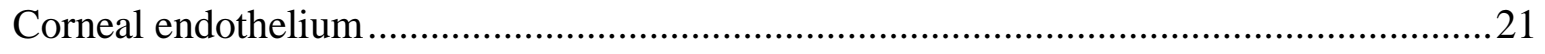

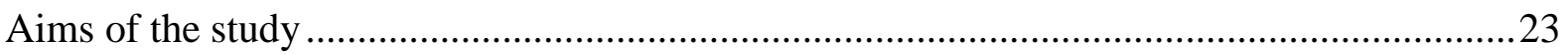

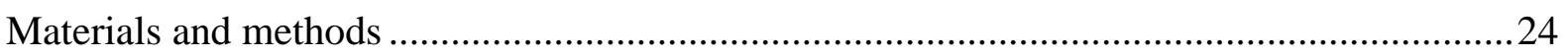

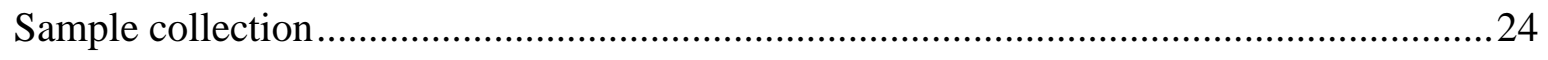

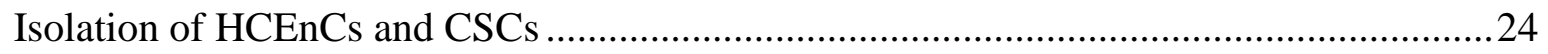

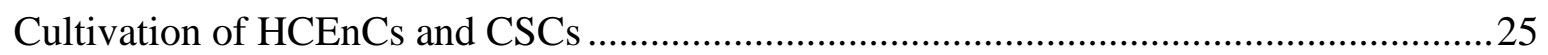

Reverse Transcription - Quantitative Polymerase Chain Reaction (RT-qPCR) analysis ...26

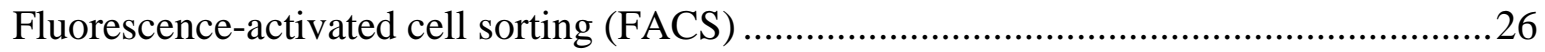

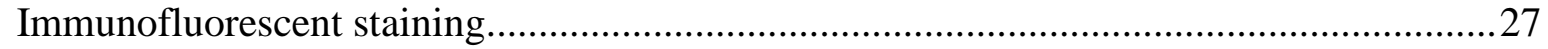

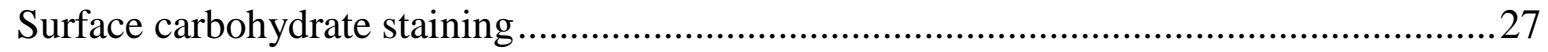

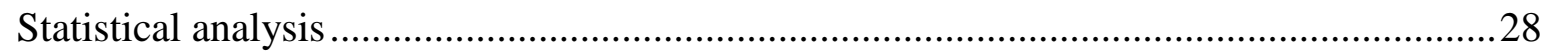

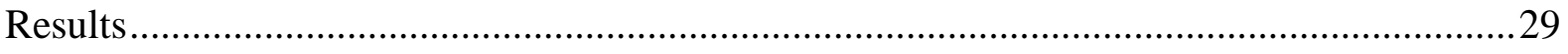

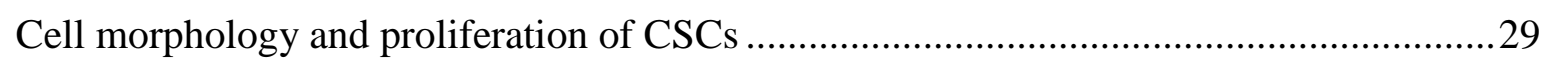




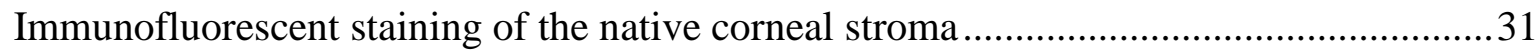

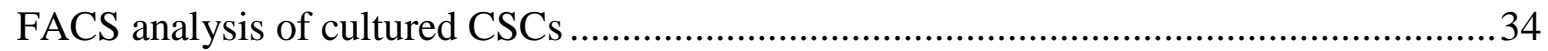

Gene expression in the native- versus cultured cells of the corneal stroma ........................36

Comparison of the gene expression of B4G12 and primary HCEnC to CSCs ...................37

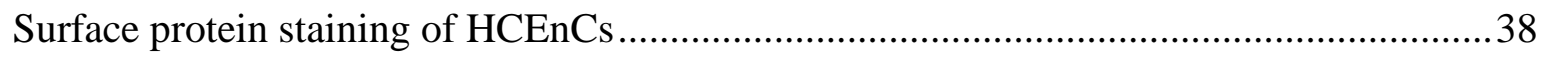

Surface lectin-carbohydrate pattern of primary HCEnCs ............................................. 41

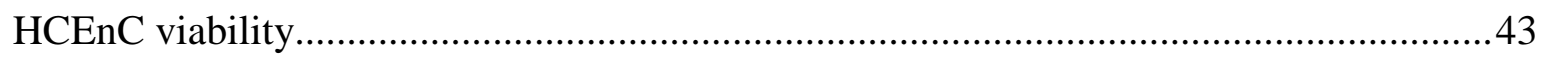

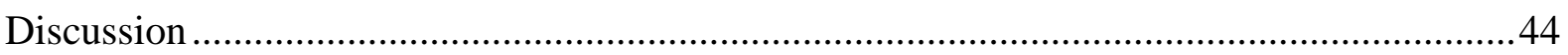

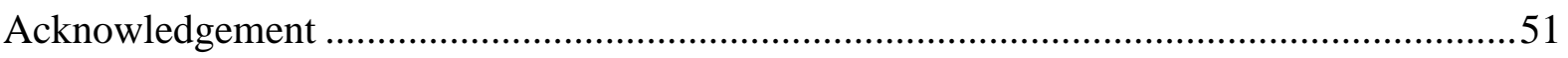

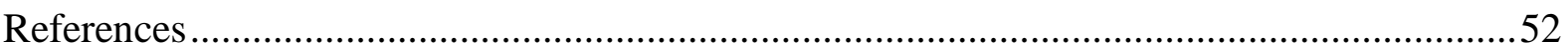




\section{List of abbreviations}

18S RNA 18s ribosomal ribonucleic acid

ABCG2 ATP-binding cassette sub-family G member 2

ABCG5 ATP-binding cassette sub-family G member 5

Ab/am Antibiotic/antimycotic solution

ALDH1A1 Aldehyde dehydrogenase 1

ANOVA Analysis of variance

APS Allophycocyanin

ATCB Actin B

ATMP Advanced therapy medicinal product

AQP1 Aquaporin 1

BCSC Bovine corneal stroma cell

BMMSC Bone marrow-derived mesenchymal stem cell

BSA Bovine serum albumin

bFGF Basic fibroblast growth factor

CD Central digested

CD\# Cluster of differentiation

cDNA Complementary deoxyribonucleic acid

CE Central explant

Con A Concanavalin A

CSC Corneal stroma cell

CXCR4 C-X-C chemokine receptor type 4 
DAPI

DBA

DMEK

DMEM

DNA

(D)PBS

DSAEK

ECM

EMT

EndoMT

ENG

FACS

FBS

FGF-2

FITC

FNC

GAPDH

GSL I

HCEnC

HESC

HLA-DR

HSV-1

iPSC 4',6-diamidino-2-phenylindole

Dolichos biflorus agglutinin

Descemet's membrane endothelial keratoplasty

Dulbecco’s Modified Eagle Medium

Deoxyribonucleic acid

(Dulbecco’s) Phosphate Buffered Saline

Descemet's stripping automated endothelial keratoplasty

Extracellular-matrix

Epithelial to mesenchymal transition

Endothelial to mesenchymal transition

Endoglin

Fluorescence-activated cell sorting

Fetal bovine serum

Fibroblast growth factor 2

Fluorescein isothiocyanate

Fibronectin-collagen coating mixture

Glyceraldehyde 3-phosphate dehydrogenase

Griffonia (bandeiraea) simplicifolia lectin I

Human corneal endothelial cell

Human embryonic stem cell

Human leukocyte antigen - antigen D related

Herpes simplex virus 1

Induced pluripotent stem cell 
ISCT

ITGAV

ITGB4

ITS

KLF4

KSPG

LCA

LESC

LSCD

MSC

N.m.

$\mathrm{Na} / \mathrm{K}$-ATPase

$\mathrm{NF}-\kappa b$

PCR

PD

PE

PHA E

PHA L

PNA

PFA

PI

PSA

RCA 120
International Society for Cellular Therapy

Integrin alpha-V

Integrin beta-IV

Insuline- transferrin- selenium solution

Kruppel-like factor 4

Keratan sulphate proteogylcans

Lens culinaris agglutinin

Limbal epithelial stem cell

Limbal stem cell deficiency

Mesenchymal stem cell

Not measured

Sodium/Potassium adenosine triphosphatase

Nuclear factor- kappa beta

Polymerase chain reaction

Peripheral explant

Peripheral digested

Phaseolus vulgaris erythroagglutinin

Phaseolus vulgaris leucoagglutinin

Peanut agglutuninin

Paraformaldehyde

Propidium iodide

Pisum sativum agglutinin

Ricinus communis agglutinin I 
RNA

ROCK

RT-qPCR

RQ

SBA

SD

SEM

sWGA

TAC

TGF $\beta 1$

TGF $\beta 3$

UEA I

VE-dadherin

WGA

ZO-1
Ribonucleic acid

Rho kinase inhibitor

Reverse transcriptase quanitative polymerase chain reaction

Relative quantity

Soybean agglutinin

Standard deviation

Standard error of mean

Succinylated wheat germ agglutinin

Transient amplifying cells

Transforming growth factor- beta 1

Transforming growth factor- beta 3

Ulex europaeus I

Vascular endothelial cadherin

Wheat germ agglutinin

Zonula occludens- 1 


\section{Magyar nyelvü összefoglaló}

\section{Irodalmi háttér}

A szem legkülső része a cornea (szaruhártya), az anterior szegmens része. A szem fénytörő képességének 2/3-át adja és fényt fókuszál a retinára. Feladata a mechanikai védelem különböző pathogénektöl, mikróbáktól, így barrierként szolgál a külső behatások ellen. Fiziológiás állapotban erek nem találhatóak a szövetben, a tápanyagok diffúzióval jutnak el a sejtekhez a könnyből, illetve a csarnokvízből, az oxigénfelvétel pedig a levegőböl történik. Három főbb, sejtek által alkotott részre bontható, ezek kívülről befelé haladva, a szaruhártya epithelium, stróma és endothelium, melyeket acelluláris membránok választanak el. A cornea epitheliumot 5-6 réteg folyamatosan osztódó, el nem szarusodó hám alkotja. A sejtek utánpótlása folyamatos, mivel a pislogás által azok száma csökken. A szem felszíni rétegét érintő trauma esetén sejtproliferáció és migráció indul meg a cornea középpontja felé, centripetálisan. Ilyenkor a limbális régióból, a cornea és a sclera határától ún. limbális epithel őssejtek vándorolnak a trauma helyére, miközben lépésenként differenciálódnak. A stróma, mely a cornea tömegének 90\%-át alkotja, egy rugalmas szövet, mely föleg vízből, proteoglikánokból és I-es típusú kollagénből áll. Elszórtan helyezkedő keratocyták szintetizálják a szövetet felépítő extracelluláris mátrixot. A stróma kb. 200, ortogonálisan elhelyezett, párhuzamos kollagénrostok által alkotott rétegből áll, lehetővé téve a szövet flexibilitását, alakját és átlátszóságát. A következő réteg a szaruhártya endothelium, mely nem a klasszikus vaszkuláris endothelium, mivel feladata a cornea víz homeosztázisának szabályozása. A sejtek morfológiája polygonális, tömött réteget alkotnak és közvetlenül érintkeznek a csarnokvízzel, így szabályozva a víz mozgását aktív molekuláris pumpáik segítségével.

A szaruhártya képes regenerálni kisebb, a felszínt érintő sérüléseket, viszont ha a trauma a mélyebb rétegeket is érinti, a krónikus gyulladás miatt kialakuló homály károsíthatja a látást, vakságot is okozhat. A trauma mellett egyéb betegségek is érinthetik a szövetet, föleg allergiás reakciók, mikrobiális fertőzések, vagy keratitisek (szaruhártya gyulladások), viszont ennél súlyosabbak a genetikai úton örökölt cornea disztrófiák, melyek általában mindkét szemben kialakulnak. Ilyen esetekben a végső megoldás részleges, vagy teljes szaruhártya transzplantáció. Szövetbankokban tárolt, kadaverekből eltávolított donor szövetek kerülnek beültetésre, viszont a világszerte tapasztalt donorhiány miatt ez nem jelent 
hosszú távú megoldást a jövőben, valamint egyes betegeken meg kell ismételni a beültetést, szövetrejekciók és egyéb okok miatt.

A regeneratív orvoslás jelenthet megoldást, az ős/sejteket alkalmazó terápiás eljárások egyre népszerübbek. Az embrionális őssejtek használata etikailag vitatott és bizonyos tanulmányok bebizonyították azok tumorigén hatását. Az indukált pluripotens őssejtek is rendkívüli potenciállal rendelkeznek, viszont itt is fenn áll a tumorigenezis lehetősége a pluripotens állapot indukciója alatt. A felnőtt mesenchymális őssejtek jelethetnek megoldást, melyek differenciációs képessége limitált, de képesek a natív szövet regenerálásra a lokális őssejt populáció helyreállításával, valamint gyulladáscsökkentő, immunmoduláló hatásuk is ismert. Állatokat alkalmazó tanulmányokban már bizonyították a felnőtt őssejtek szövetregeneráló képességét, különböző eljárások már humán klinikai fázisban vannak, viszont a többségük még kutatás alatt áll. Az egyetlen, őssejteket alkalmazó, szemészeti indikációjú gyógykészítményt 2015-ben engedélyezték, viszont használata limitált a szaruhártya epithelium és a cornea felszín regenerálásra.

\section{Célok}

1. Célunk annak a vizsgálata, hogy a különböző régiókból és eltérő módszerekkel elöállított cornea stróma sejtkultúrák különböznek-e egymástól.

2. A szaruhártya stróma különböző, anatómiailag eltérő régióiból kinyert, tenyésztett sejtek karakerizálása, specifikus, sejtfelszíni őssejt, adhéziós és egyéb markerek segítségével.

3. Van-e különbség az ex vivo tenyésztett, strómából izolált sejtek, a natív állapothoz képest, különböző funcionális-, őssejt-, adhéziós- és proliferációs gének és proteinek expressziójában.

4. Humán cornea endothel sejtek izolálása és tenyésztése, fenotípusos karakterizálása.

5. Szaruhártya strómából izolált és cornea endothel sejtek génexpressziójának összehasonlítása funkcionális és specifikus, korábban leírt markerek segítségével. 
6. Tényesztett szaruhártya endothel sejtek karakterizálása sejtfelszíni fehérjék és szénhidrátok alapján, mintegy „ujjlenyomatot” létrehozva a sejtek egyszerübb azonosítása végett.

\section{Módszerek}

A kadaverekből történő szövetgyüjtést az Egészségügyi Tudományos Tanács hagyta jóvá és megfelelt a Helsinki Nyilatkozatban foglaltaknak. Mindent mintát a halál beállta utáni 24 órában gyüjtöttünk. A szemet steril fülkében, betadinos áztatás után sóoldattal mostuk, majd a szaruhártyát sebészeti ollóval eltávolítottuk és steril Petri-csészékbe helyeztük. Sztereomikroszkóp alatt a felfelé fordított corneáról az endotheliumot az alatta található Descemet membránnal együtt, csipeszek segítségével eltávolítottuk és kollagenáz oldatban inkubáltuk. Tripszines kezelést követően a sejteket egymástól is teljesen elválasztottuk, így tenyésztettük öket egy, az irodalomban használt módszert követve, két féle médium használatával. A visszamaradt szaruhártya korongon, az anterior részen egy penge segítségével óvatosan lekapartuk a cornea epitheliumot. A maradék strómát egy trepán segítségével kb. $3 \mathrm{~mm}$ átmérőjü darabokra szeltünk, majd kollagenázzal kezeltünk, illetve kezelés nélkül, direkt tenyészetőedényekbe helyeztünk. A szaruhártya endothel sejtekhez kontrollként egy ismert cornea endothel sejtvonalat használtunk (B4G12).

Paraffinba ágyazott szaruhártyákat in situ immunfestéssel vizsgáltuk, ABCG2, CXCR4, nestin, Ki-67, ALDH1A1, kollagén I., CD34, CD73, CD90, CD105, vimentin, fibronektin, kollagén IV, VE-kadherin, $\alpha$-aktinin, ABCG5, anti-fibroblaszt markerek expreszióját. Primer cornea endothel sejteket speciálisan kialakított tenyésztőedényekben expandáltunk, majd CD73, CD166, kollagén I és IV, Na/K ATPáz, ZO-1 és Ki-67 molekulák ellen termelt antitestekkel, majd hasonló módszerrel, festékmolekulákkal jelölt lektinekkel a sejtek sejtfelszíni szénhidrátjait jelöltük, majd fluoreszcens mikroszkóppal felvételeket készítettünk.

Áramlási citometriás méréshez, a tenyésztett sejteket háromféle festékmolekulához konjugált antitesttel jelöltük: ABCG2, CD31, CD34, CD44, CD47, CD49a, CD49d, CD51, CD54, CD73, CD90, CD105, CD106, CD112, CD146, CD166, CD325 és Nestin fehérjék ellen. Inkubáció után a sejteken a különböző markerek eloszlását határoztuk meg és fenotipizáltuk. 
A cornea stróma és endothelium sejteket szérumot tartalmazó médiumban tenyésztettük, majd a megfelelő sejt és passzázs-szám elérésekor a letapadó sejteket tripszin segítségével felvettük és totál RNS-t izoláltunk, majd reverz transzkripcióval cDNS-t szintetizáltunk. RT-qPCR módszerrel vizsgáltuk ALDH1A1, ABCG2, AQP1, CD31, CD34, CD73, CD90/THY1, Claudin 14, CXCR4, CK-19, ENG (CD105), GPC4, ITGAV, ITGB4, KLF4, Nestin, Vimentin, ZO-1 gének expresszióját.

\section{Eredmények}

A létrehozott explantált- és emésztett- stróma tenyészetekben viábilis, hosszúkás-, illetve orsó-alakú sejteket figyeltünk meg. A sejtek viszonylag gyorsan osztódtak mind a négy kondíció esetében azonos morfológiai sajátságokat mutattak. A szaruhártya stróma pozitív festődést mutatott $\alpha$-aktininre, ALDH1A1-re, CD31-re, CD34-re, kollagén I-re és Vimentinre, viszont az ABCG2, ABCG5, fibroblaszt, CD73, CD90, CD105, kollagén IV, fibronektin, Ki-67, Nestin és VE-kadherin markerek negatívak voltak. A tenyésztett stróma sejtek CD73, CD90, CD105, CD51, Nestin, CD49a, CD49d, ABCG2 és CD47 pozitívak voltak, CD34-et és CD31-et pedig nem expresszáltak. A natív human strómában szignifikánsan magasabb ALDH1A1, AQP1, ITGB4, KLF4, CXCR4, CD31 és CD34 expressziót találtunk, a tenyésztett sejtekhez képest, ahol viszont szignifiákánsan magasabb volt az ABCG2, ITGAV, Nestin, CD73, CD90, CD105 és Vimentin gének expressziója, míg a GPC4 nem volt szignifikánsan eltérő a két minta esetében. A primer szaruhártya endothel sejtekben és a sejtvonalban szignifikánsan alacsonyabb volt a Vimentin, CD90, CK-19 gének expressziója, a stróma sejtekhez képest, míg az endothel sejtekben magasabb volt a ZO-1 kifejeződése. A Claudin 14 csak a B4G12 sejtvonalban volt detektálható.

Az áramlási citometriás mérés alapján a primer szaruhártya endothel sejtek pozitívak CD166, CD47, CD44, CD54, CD73, CD90, CD105, CD106, CD112, CD146, CD325 markerekre, míg a CD34 negatív. Izolálás után, frissen jelölt cornea endothel sejtek CD73, CD90, CD146 és CD325 markereket expresszáltak. A primer szaruhártya endothel tenyészetek pozitívak voltak LCA, PHA E, PHA L, PSA, sWGA, Con A, RCA 120, WGA lektinekkel jelölve, viszont nem GSL I, SBA, DBA, PNA, UEA I lektinekre.

\section{Diszkusszió}

Jelen tanulmányban azt találtunk, hogy valószínüleg a humán szaruhártya stróma eltérő régióiból, emésztéses vagy explantátum módszerrel izolált sejtek fenotípusosan 
megegyeznek, azonos mértékben fejeződnek ki a specifikus, adhéziós, őssejt, proliferációs markerek, így a szövet bármely részéből kinyerhetőek kutatási célokra. A tenyésztett strómából származó sejtek azonban jelentős változáson mennek keresztuil, a fenotípus- és genotípus-beli változásokat figyelembe véve, a natív állapothoz képest. Amíg néhány, a natív szövetben megtalálható specifikus, funkcionális marker expressziója csökken bizonyos, őssejtek által hordozott markerek szintje nő.

Tenyésztett cornea endotheliumból izolált sejtek sejtfelszíni markereik és funkcionális gének expressziója alapján jól definiálhatók és különböznek a stróma sejtektől. A primer szaruhártya endothel sejtek olyan markereket is hordoznak, amelyek regenerálódó, integritásukban sérült szövettel asszociálhatóak. Az általunk használt és világszerte is széles körben alkalmazott módszerrel előállított szaruhártya endothel kultúrák valószínüleg mentesek szennyező stróma sejtektől, viszont a sejtek feltételezhetően endothelmesenchymális tranzíción mennek keresztül a tenyésztés során, bizonyos markerek jelenléte és morfológiai változások alapján.

Konklúzióként elmondható, hogy a humán szaruhártya stróma és endothel rétegeiből izolált sejtek stabilan szaporíthatóak laboratóriumi körülmények között és az általuk kifejezett gének és sejtfelszíni markerek alapján jelentős potenciállal rendelkeznek, mindezt számos kutatási eredmény alátámasztja. Fontos, hogy a jövőbeli kutatások célja olyan funkcionális, standardizált módszerekkel előállított sejtek előállítása, melyek terápiás alkalmazhatósága, biztonsága és biokompatibilitása kutatási eredményekkel alátámasztott és klinikai körülmények között alkalmazhatóak a szem elülső szegmensét érintő patológiás elváltozások gyógyítására. 


\section{Introduction}

The outermost layer of the human eye is the cornea (Figure 1). Its outstanding properties such as avascularity and transparency enable the humans to see the world through it. The cornea is responsible for refraction of the incoming light, admitting and focusing it onto the retina. Furthermore, it serves as a protective barrier against microbes, pathogens and air-borne substances, as well as mechanical stimuli. The average diameter of the cornea is approximately $11.5 \mathrm{~mm}$ with $0.5-0.7 \mathrm{~mm}$ thickness. Physiologically, blood vessels do not penetrate the tissue, instead nutrients reach the cells via diffusion from the tear film at the ocular surface or from the aqueous humor on the posterior side, secreted by the ciliary body; oxygen is absorbed directly by the cornea from the air.

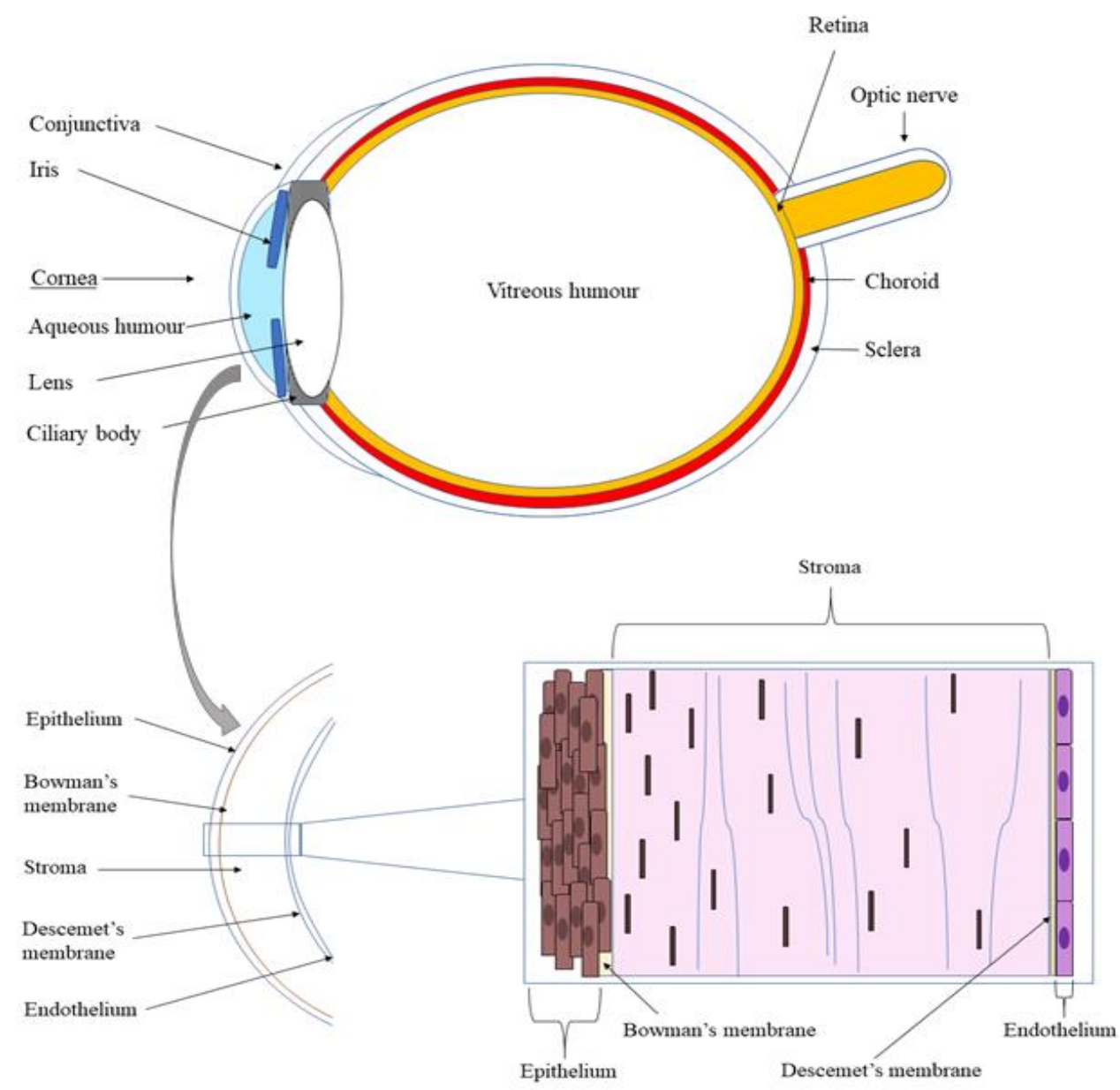

Figure 1. A schematic of the major anatomical structures of the human eye and the cornea.

Anterior to posterior direction, the human cornea has 5 officially recognized layers, the corneal epithelium being the foremost. This cellular layer - the first barrier of the eye against 
the outside world - consists of 5-6 strata of fast-cycling, non-keratinizing, squamous epithelial cells. As blinking constantly sheds the outermost layer, replacement of the epithelial cells from the underlying strata is continuous, under physiological conditions. The next layer is a thin, acellular interface membrane made up of collagen fibers - the so-called Bowman's layer, which separates the corneal epithelium from the stroma. (Figure 1)

Occupying $90 \%$ of the thickness of the cornea, the stroma is a flexible layer, made up of water, proteoglycans and abundant amounts of collagen type I. The stroma is responsible for $2 / 3$ of the refractive power of the eye. It is scarcely populated by quiescent keratocytes known to synthesize the proteoglycans and collagens that make up the tissue. [1] This complex network of approximately 200 layers of uniform collagen I and V fibrils is remarkable. The specific ultrastructural features enabling the dome-like shape of the tissue, stability, mechanical flexibility and orthogonally- stacked lamellae render the tissue completely transparent. Interestingly, the fibrils are uniform in diameter, around $31 \mathrm{~nm}$ in humans. [2] The proteoglycans- mostly keratin and chondroitin- or dermatan-sulphate- bind to the collagens, forming bridges across the tissue. The fibers stretch towards the sclera where the arrangement changes to grouped. The corneal stroma develops from the neural crest during embryogenesis, which is also the origin of the mesenchymal tissues of the head.

Adjoining to this is the presence of a recently described anatomical structure - the Dua's layer, which is still debated in the scientific and medical community, however, it is thought to be an acellular structure, located between the stroma and the Descemet's membrane. [3] Another interface layer, the Descemet's membrane, is thought to be acellular as well, serving as a basal membrane to support the corneal endothelium. Despite its name, the endothelial layer is not a classical vascular endothelium, however, it is made up of polygonal (mostly hexagonal), tightly adjoined cells, and is a squamous epithelial tissue. The cells are in direct contact with the aqueous humor (Figure 1), nourishing the endothelium, while oxygen is absorbed from the air. Corneal endothelial cells have a crucial role in the hydration of the stroma and the cornea as a whole, regulated by active molecular pumps on the cells' surface, under physiological circumstances, essential in achieving perfect transparency.

The cornea is exposed to external damage, being the foremost layer of the eye, and is able to recover from minor superficial wounds without complications. Deeper injuries and accompanying inflammation can severely impair vision and can cause chronic corneal blindness through haze formation. One of the most common conditions that affect the eyes is 
pollen allergy, causing minor discomfort, while the second most common one is the dry eye syndrome, mostly caused by air-conditioning devices. The acute inflammation of the cornea, keratitis is usually classified as non-infectious and infectious type. The first type, is usually brought about by minor scratches, while the second type is brought by microbial infections provoked by contact lens wear or any other infections of the ocular surface that is treated by antibacterial and/or steroid eye drops.

Corneal dystrophies are usually genetically inherited diseases, affecting both eyes. The conditions gradually progress, eventually leading to haze due to the dysfunction of one or more layers of the cornea. Most common of them is keratoconus, where thinning of the cornea makes the tissue to protrude and adopt a cone-like shape, as the name suggests. The exact causes are unknown and in most cases the cornea becomes stable after a few years of treatment, or in some cases the condition progresses, the symptoms worsen with the vision decreasing gradually and scarring occurs. Ultimately, corneal transplantation is the last and definite option for treatment.

Fuchs' dystrophy affects both eyes of mostly women and is another slowly progressing condition. The number of corneal endothelial cells decreases to a critical number and subsequently, fluid leakage into the cornea causes local edema, swelling and vision impairment. Therapy normally targets the reduction of swelling, although severe cases require transplantation. In lattice dystrophy, amyloid deposits appear in the corneal stroma, forming a lattice-shaped accumulation of the protein, gradually overtaking the stroma, often destructing the epithelium in the process. Corneal transplantation is the last line of therapy in severe cases, although the disease is known to be intermittent. Other conditions that can affect the cornea are Herpes Zoster infection and reactivation (from latency after chickenpox infection), or Herpes caused by herpes simplex virus- 1 (HSV-1), creating sterile non-healing ulcers in the cornea that can turn into stromal keratitis. [4]

Therapy of the most severe diseases includes full thickness- or partial (lamellar) transplantation of the cornea, however, there is a global shortage of donors, reportedly 1 cornea is available for 70 needed. [5] Success rates for engraftment are relatively high, with a 5-30\% rejection rate. [6] Alternatively, keratoprosthesis (Kpro), an artificial cornea is sometimes the last resort for patients who had rejected multiple cornea transplantations. Despite the high success rates, complications can always from surgery occur, such as glaucoma, dislocation and local inflammation of the surrounding tissue. [7] 
Since human donor tissue is scarce and at the same time transplantation is the only solution in the therapy of severe cases, alternative methods are called upon. Regenerative medicine could fill the void, as cellular therapies using stem cells are gaining momentum. The main challenge is represented by the distinct roles and functionality of the cells making up the cornea. Stem cells possess the ability and plasticity to turn into multiple types of cells in which they are located. Besides embryonic, adult mesenchymal and hematopoietic stem cells need to be specified. The ethical use of human embryonic stem cells (HESCs) is highly debated; furthermore, long-term studies have associated a tumorigenic potential to these cells. Induced pluripotent stem cells (iPSCs) have been generated by reprogramming differentiated cells and while these cells have similar properties for renewal, as embryonic progenitors, autologous iPSC have been known to activate the immune system and the reprogramming itself carries certain risks for tumor formation. On the contrary, adult stem cells have been shown to have a low potential to tumorigenesis, with equal beneficial effects in tissue regeneration by the replenishment of native stem cell pools, and specifically, adult mesenchymal stem cells (MSCs) have been attributed immunosuppressive effects [8-11]. Nevertheless, certain types of adult MSCs are known to have a limited renewal capacity. Although stem cell research and regenerative therapy for the cornea is currently being undertaken worldwide, most of the methods utilizing tissue engineering and cellular therapy are under development or still in research stage, while only a few have made it to clinical trial phase.

\section{Corneal epithelium}

The corneal epithelium consists of 5-6 layers of closely packed cells (Figure 1) that quickly respond to any superficial damage affecting the layer. Cells are continuously shed by blinking and are replenished from stem cell niches, located at the basal epithelium of the corneoscleral border - the limbus. In this special microenvironment, protected by the eyelids, the progenitor cells of the corneal epithelium or limbal epithelial stem cells (LESCs) can maintain the undifferentiated state and renew the stem cell pool. A damaged or lost corneal epithelium induces centripetal migration of the LESCs from the niches towards the affected area, gradually differentiating into transient amplifying- (TAC), then mature epithelial cells. [12] Due to the asymmetrical division displayed by LESCs -and stem cells in general, this capability of self-renewal enables the cells to completely regenerate the epithelial surface in the course of 12-24 hours. [13] Loss of LESCs, usually induced by chemicals, mechanical 
injuries or disease is a severe threat to the regenerative capacity of the corneal surface. During this condition known as limbal stem cell deficiency (LSCD), epithelial cells of the conjunctiva start proliferating and migrating towards the center of the cornea, attracting vessels and leading to corneal neovascularization, thus causing blindness.

Autologous transplantation of limbal biopsies taken from contralateral, good eye of patients or close relatives, have been shown to have therapeutic benefit, and been around in use for the last 25-30 years [14], holding a success rate of 80\%. [15] The LESCs can be obtained from cadaveric tissue as well, however, this requires systemic immunosuppression, demonstrating lower success rates in long-terms. [16] The amniotic membrane, an avascular tissue and a byproduct from child delivery, has been known to possess anti-inflammatory and anti-angiogenic properties and been used to cover up limbal grafts to decrease the chance of rejection; the amniotic membrane has beneficial effects on its own, as well, in the prevention or treatment of partial LSCD. [17]

It was in 1997, that LESCs from limbal biopsies have been cultivated ex vivo, then reimplanted into the patients, showing long- lasting positive outcomes. [18] Animal-free medium has also been used to culture and expand the cells in vitro. [19] According to recent studies, contact lenses are appropriate carriers for the reintroduction of LESCs into recipients' eyes. [20] Despite the promising results, the success rate of such procedures is around $70 \%$, and the method is not always sufficient for optimal recovery of vision. [21] In 2015, the European Commission approved the commercialization of the first ATMP (advanced therapy medicinal product) using stem cells, called the Holoclar ${ }^{\circledR}$, a technique using ex vivo expanded LESCs from biopsies and is a cornerstone of ocular regenerative medicine; however, its potential appears to be limited to the treatment of superficial damage (affecting only the corneal epithelium). [22]

\section{Corneal stroma}

Keratocytes are responsible for the maintenance of the corneal stroma and its uniquely elaborate structure and consistency. These cells assume a dendritic morphology in vivo, however, during wound healing the cells can transform into myofibroblasts and deposit scar tissue, hampering the corneal transparency and adversely affecting vision. [23, 24] Stromal tissue obtained from cadavers and cultured in serum-containing media gives rise to adhering cells displaying a spindle-shaped morphology and a steady proliferation rate. [25] 
Interestingly, corneal stroma cells (CSCs) in vitro, have been found to express markers that are usually present on adult MSCs. The distribution of these surface protein markers (e.g.

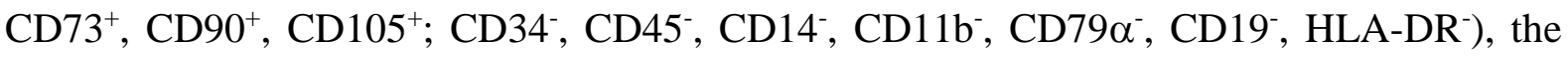
cells' adherence to plastic and the ability to perform the canonical trilineage differentiation into adipose- (fat), cartilage- and bone tissues in vitro, enables these cells to be considered as adult MSCs, as defined by the ISCT (International Society for Cellular Therapy). [25-29] Another ability of MSCs - the immunosuppressive properties through secretion of antiinflammatory cytokines, has also been confirmed on CSCs. [30, 31] Studies conducted on animals proved the true potential of CSCs in cellular therapy. [32] The true origin of these cells is still debated, however and possibly, isolation of such cells activates them and/or different populations become dominant. [29, 31, 33] Various types of cultivation media induce the in vitro stem cell phenotype of CSCs in different ways [34], and low serum or serum-free conditions have been shown to restore the keratocyte phenotype, at the expense of viability and ECM production. [35]

The most challenging part of corneal stroma-oriented regenerative research is the reproduction of the fine ultrastructure, arrangement and composition of the stroma itself. CSCs cultured in serum-containing medium secrete abundant amounts of ECM into the vessel. A study using 10\% serum and ascorbic acid in the cultivation medium found that the ECM appeared to have a great resemblance to the composition of the native tissue, including collagens and sulphated proteoglycans, as well as apical-basal polarity of the cultured CSCs. $[36,37]$ Addition of transforming growth factor (TGF) $\beta 1$ and $\beta 2$ to the medium induced the deposition of fibrotic-, scar-like ECM in the cultures, while TGF $\beta 3$ enhanced the production of normal, non-fibrotic structures- similar to the one by the control (no TGF)-, with an increased thickness of 60-70 $\mu \mathrm{m}$ to $20 \mu \mathrm{m}$. [38] The production of de novo connective tissue in culture provides the cells a major advantage in tissue-engineering-based research and possible future clinical implication; however, this "in vitro tissue" does not replicate the flexibility and other biomechanical features of the cornea completely, as of yet. This led to another branch of corneal stroma-based research with an attempt to repopulate decellularized animal-derived corneas by human CSCs, thus minimizing the risk of rejection from xenotransplantation. $[39,40]$

Despite the ever-growing body of evidence, research groups worldwide have access to corneas from different sources (e.g.: waste from keratoplasties, tissue banks, morgues) and 
use various methods to obtain CSCs. There has not been a study to date investigating, whether there is any phenotypical difference in the cells or in the expression of specific genes generated by an enzymatic [27, 41] or an explant [25] technique from different anatomical regions of the cornea. The evidence about CSCs is not as extensive as of LESC research, although, the potential of CSCs is undebated and the beneficial effect of MSCs in corneal reconstruction has been demonstrated in animal experiments [42-44], but the probability of applying the cells in clinical practice is still in its infancy.

\section{Corneal endothelium}

The most posterior layer of the cornea is not the classical vascular endothelium, instead it is made up of a single layer of tightly-packed squamous epithelial cells, responsible for the water homeostasis of the cornea. Initially, it was thought that these cells do not proliferate and are arrested in the $\mathrm{G}_{1}$ phase of the mitosis. If a cell dies, a neighbouring one would enlarge and fill in the gap left behind. Through aging or defects in the corneal endothelium, as cell density drops below a critical number, excess water leaks into the anterior cornea causing local edema, and damage to the tissue and ultimately vision impairment occurs. Recent discoveries led to a turning point in the way corneal endothelium is approached - it has been found capable of recovering from minor wounds. [45] Presence of a putative progenitor cell population at the transitional zone between the corneal endothelium and the trabecular meshwork, called Schwalbe's line has been suggested in one study [46], as the source of precursor cells for both tissue types. Another study points at an increased density of cells around the peripheral endothelium, presumably identifying a renewed population of cells. [47] Wound healing studies reported appearance of stemness markers in the peripheral corneal endothelium [48], although another study reported proliferative activity in only $10 \%$ of wounded samples. [49] Still not conclusive, these results suggest, that the corneal endothelium is possibly capable for a delayed replacement of dead cells of the layer in vivo.

Ongoing corneal endothelial research has been focused on the expansion of these cells in vitro. Production of viable, steadily proliferating and homogenous human corneal endothelial cell (HCEnC) cultures and thus reproducible data has been a major challenge of the past 30 years. Cultured HCEnC (re)gain the ability to proliferate in vitro, using serum-containing medium [50] at the expense of morphological shift, loss of functionality and possible contamination by other cell types. [51, 52] The cells in vivo, assume a perfect polygonal (hexagonal) morphology, while in culture a more polarized, elongated shape is present in 
long-terms. The process is thought to be the endothelial (epithelial)- mesenchymal transition (EndoMT or EMT), regulated by TGF 32 , causing a rearrangement of the microfilament system. [53] Several studies have used Rho kinase inhibitors (ROCK) to constrain EMT by blocking the rearrangement of the microtubules temporarily, while affecting cell motility and proliferation. [54-57] There are a few commercialized cell lines, although none of them represent the original cells adequately, as suggested by genomic analysis. [58] HESCs have been successfully differentiated into HCEnCs, expressing functional markers, such as zonula occludens-1 (ZO-1) and $\mathrm{Na} / \mathrm{K}$ ATPase [59], however the use of HESCs faces ethical problems and will not provide a long-term solution for the generation of clinically favorable products.

Isolation of the cells from the corneal endothelium is usually achieved with the separation of the supporting Descemet's membrane. Enzymatic treatment causes release of the cells from the basal membrane and dissociation from each other by the breakup of the tight junctions. [60] The single cells attach to pre-treated culture vessels, exhibiting a sluggish expansion rate. Initially the cells display polygonal-like morphology, which then shifts into a more polarized cell shape, reportedly due to contamination by stromal cells or as a result of EMT. A few markers have been suggested for the assessment of HCEnC culture purity, such as CD166/ALCAM [51], glypican-4 and CD200 [61], a study even details markers found on a sorted population of HCEnCs. [62]

A pre-clinical trial performed on monkeys proved to be unsatisfactory, when HCEnCs expanded on collagen I sheets were implanted; in another study, 243 patients were treated with injection of corneal endothelial cell suspension in a minimally invasive procedure. [63] In the current study, HCEnC cultures have been generated by a method widely used by the scientific community [60], to characterize the expression of certain surface proteins and carbohydrates/ glycocomplexes, to set up a more robust "fingerprint" panel for the identification of these cells and to assess purity and homogeneity of the cultures. The role of protein and carbohydrate homeostasis of the cell has been implicated in events, such as cell adhesion, differentiation, development and cancer cell metastasis [64], therefore, it is generally a good indicator of the cells' state and potential. Ample amount of research needs to be undertaken to set up the optimal, "golden standard" method for the successful isolation and cultivation of HCEnCs for tissue engineering and possible use in future clinical therapeutic procedures. 


\section{Aims of the study}

1. To investigate, whether various isolation methods can generate different populations of CSCs.

2. To characterize cultured CSCs produced by the different methods and various anatomical regions in regards to their distribution of specific surface- markers' expression related to stemness and cellular adhesion.

3. To explore the magnitude of change that CSCs go through, when expanded ex vivo by comparing the gene and protein expression demonstrated by the native versus cultured cells and in regards to markers related to functionality, stemness, adhesion and proliferation.

4. To isolate and cultivate cells from human corneal endothelium and explore their phenotypic characteristics.

5. To compare the gene expression of certain function-related and other previously described markers in CSCs versus HCEnCs.

6. To characterize the state of HCEnCs based on their surface protein and carbohydrate distribution and thus generate a fingerprint capable of assessing the purity of cultured cells. 


\section{Materials and methods}

\section{Sample collection}

Collection of cadaveric tissue was approved by the Hungarian National Medical Research Council (14387/2013/EKU-182/2013) and complied with the directives of the Helsinki Declaration. All specimens were obtained within 24 hours of death.

\section{Isolation of HCEnCs and CSCs}

The bulbi were thoroughly disinfected in $5 \%$ povidone iodine (Egis) for 30 seconds, then rinsed with sterile Dulbecco's phosphate-buffered saline (DPBS). Corneal buttons were dissected with the help of surgical scissors. Facing down, the corneas were placed in sterile Petri dishes. Under a surgical stereomicroscope, the corneal endothelium and the underlying Descemet membrane were separated from the stroma with an angled crescent knife and a pair of forceps. The tissue was moved into a separate tube and was treated with $1 \mathrm{mg} / \mathrm{mL}$ collagenase solution ( $\geq 125 \mathrm{CDU} / \mathrm{mg}$, Sigma) in $15 \mathrm{~mL}$ centrifuge tubes for 3 hours at $37^{\circ} \mathrm{C}$ with gentle rocking, in order to separate the HCEnC from the Descemet membrane. Serum containing culture medium was added to the tubes to neutralize the enzyme. Following a gentle spin at 800 RPM for 5 minutes, cells were treated with trypsin-EDTA (Sigma) to produce single cells. After a 5-minute incubation at $37^{\circ} \mathrm{C}$, culturing medium was added and the cells were pelleted again at 800 RPM. HCEnC were plated in FNC coated (fibronectincollagen mixture, Thermo Fischer) 24-well culture plates (Corning Costar, Sigma).

After removing the corneal endothelium and Descemet membrane, the leftover tissue was carefully scraped using a surgical scalpel to decrease the chance of contamination by corneal epithelial cells. With the help of trephine, pieces of tissue measuring $3 \mathrm{~mm}$ in diameter were generated by punching through the stroma. Pieces were collected from central and peripheral stromal regions (Figure 2)

One part of the pieces from the two regions were used for enzymatic digestion in $3 \mathrm{mg} / \mathrm{mL}$ mixed collagenase (Sigma, USA) for 3 hours at $37^{\circ} \mathrm{C}$, while the other half was placed directly into 6-well culturing dishes (Corning Costar, Sigma). Four types of CSC cultures were created, namely: central explant (CE), peripheral explant (PE) versus central digested (CD) and peripheral digested (PD) from the same donor. 


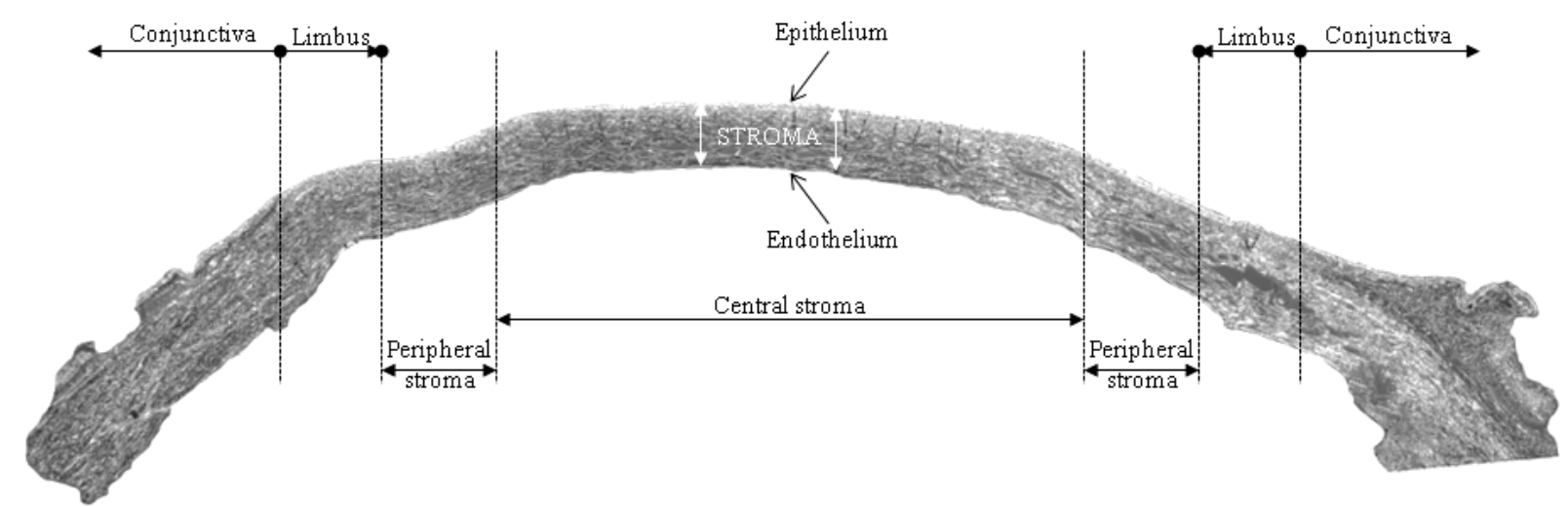

Figure 2. Major anatomical regions of the human cornea. The corneal endothelium was peeled off the posterior part of the tissue together with the underlying Descemet membrane. The corneal epithelium was scraped off to expose the "naked" stroma. A surgical trephine was used to generate punches of tissue from the central or peripheral stroma. The picture was taken by an EVOS ${ }^{\circledR}$ fluorescent microscope (Thermo Fisher Scientific).

\section{Cultivation of HCEnCs and CSCs}

As a control for primary HCEnCs, a commercially available corneal endothelial cell line was used. Namely, the B4G12 cell line was purchased (Leibniz-Institut DSMZ-Deutsche Sammlung von Mikroorganismen und Zellkulturen $\mathrm{GmbH}$ ) and the cells were seeded onto chondroitin-sulphate-laminin coated 24-well culture plates (Corning Costar, Sigma) and Human Endothelial Serum Free Medium (Thermo Fisher) was applied and changed every alternate day. A preformulated, fibronectin- collagen mixture (FNC coating mix, Thermo Fisher) was used to pre-treat primary HCEnCs culture plates. Initially, primary cells were incubated in attachment medium with 5\% fetal bovine serum (FBS) (Biosera) and 1\% antibiotic/ antimycotic (ab/am) solution (PAA Laboratories $\mathrm{GmbH}$ ) in Endothelial Serum Free Medium for the first 2 days. On the third day, maintenance medium was applied, containing Ham's F12/M199 containing 5\% FBS, 1\% ab/am solution, 1\% insulin transferrin selenite (ITS) (Sigma-Aldrich, USA), $10 \mathrm{ng} / \mathrm{mL}$ basic fibroblast growth factor (bFGF) (Biovision) and $0.02 \mathrm{mg} / \mathrm{mL}$ ascorbic acid (Duchefa Biochemie). Medium was changed every alternate day. [65]

CSCs were plated and cultured in DMEM Low glucose (Sigma) supplemented with 10\% FBS and $1 \% \mathrm{ab} / \mathrm{am}$ solution. Cell were kept at at $37^{\circ} \mathrm{C}$ with $5 \% \mathrm{CO}_{2}$ under adhesive conditions. Medium was changed on alternate days. For immunostaining and FACS experiments, CSCs were subcultured in T150 flasks (TPP, Sigma,). 


\section{Reverse Transcription - Quantitative Polymerase Chain Reaction (RT-qPCR) analysis}

Total RNA from B4G12 cells, HCEnCs and CSCs was isolated by RNeasy mini kit (Qiagen) according to the manufacturer's protocol. In case of primary HCEnCs, total RNA was extracted using TRIzol Reagent (UD-GenoMed). Reverse transcription was performed using the High Capacity cDNA Archive Kit (Applied Biosystems) with 200 ng total RNA per $20 \mu \mathrm{l}$ RT reaction. For B4G12, cDNA was amplified on an Mx3005P PCR system (Stratagene, Agilent Technologies).

As a control for the CSCs, total RNA was isolated from the native corneal stroma, as well, using Qiazol reagent (Qiagen). Samples were homogenized by QIAshredder columns (Qiagen) or Tissue Ruptor probes (Qiagen). NanoDrop was used to determine RNA concentrations (Thermo Fisher Scientific). Superscript III reverse transcriptase and random hexamers (Life Technologies) were used to transcribe RNA into cDNA. Taqman Gene expression assays were purchased and a StepOnePlus system (Applied Biosystems) was used to assess relative gene expression levels. ALDH1A1 (Hs00605167_g1), ABCG2 (Hs01053790_m1), AQP1 (Hs01028916_m1), CD31 (Hs01065279_m1), CD34 (Hs00990732_m1), CD73 (Hs01573922_m1), CD90/THY1 (Hs00174816_m1), claudin14 (Hs 00273267_s1), CXCR4 (Hs00607978_s1), cytokeratin-19 (Hs 00761767_s1), ENG (CD105) (Hs00923996_m1), GPC4 (Hs00155059_m1), ITGAV (Hs00233808_m1), ITGB4 (Hs00236216_m1), KLF4 (Hs00358836_m1), Nestin (Hs00707120_s1), Vimentin (Hs 00185584_m1), ZO-1 (Hs 01551861_m1) were assayed. Thermo cycling conditions were set as $95^{\circ} \mathrm{C}$ for 10 minutes, followed by 40 cycles of $95^{\circ} \mathrm{C}$ for 15 seconds and $60^{\circ} \mathrm{C}$ for 1 minute. Analysis was carried out by the $2^{-\Delta \Delta \mathrm{Ct}}$ method and fold-changes (RQ) in gene expression were determined relative to HCEnCs, CSCs or the native corneal stroma. GAPDH (Hs99999905_m1) and 18S RNA (Hs03003630_g1) were used as housekeeping genes. All samples were run in triplicates.

\section{Fluorescence-activated cell sorting (FACS)}

For surface protein analysis, cells were collected by trypsinization. Following a centrifugation at 1000 RPM, 10 minutes, the cells were resuspended in FACS buffer $(0.05 \%$ Na-azide and $0.5 \%$ BSA in DPBS). Fluorescein-isothiocyanate (FITC), phycoerithrin and allophycocyanin (APC) conjugated primary antibodies against ABCG2, CD31, CD34, CD44, 
CD47, CD49a, CD49d, CD51, CD54, CD73, CD90, CD105, CD106, CD112, CD146, CD166, CD325, Nestin were incubated with the cells for 30 minutes at $4^{\circ} \mathrm{C}$. Cells were spun again and fixed by $1 \%$ paraformaldehyde (PFA). A FACS Calibur cytometer (BD, Biosciences, Immunocytometry Systems) was used to determine fluorescence intensity of the given markers. Results were analyzed by Flowing Software 2.5 (Perttu Terho, Turku Centre for Biotechnology) and FCS Express 6 (De Novo Software). R software (version 3.3.0., R Foundation for Statistical Computing) was used to carry out hierarchical clustering of CSCs. [25]

\section{Immunofluorescent staining}

In situ protein expression was prepared on paraffin-embedded corneas to study progenitor and stem cell (ABCG2, CXCR4, Nestin), proliferation (Ki-67), functional (ALDH1A1, Collagen I, CD34), MSC markers (CD73, CD90, CD105, Vimentin), cellular and matrix adhesion components (Fibronectin, Collagen IV, VE-Cadherin) and other molecules ( $\alpha$-actinin, ABCG5, anti-fibroblast marker). After deparaffinization, non-specific binding sites were blocked by 5\% BSA (Sigma-Aldrich) for 1 hour at room temperature. The primary antibodies were incubated with the samples overnight at $4^{\circ} \mathrm{C}$. The next day, slides were washed for 5 minutes three times in PBS containing 0.01\% Tween-20 (PBST). Alexa Fluor 488 secondary antibodies were applied for 1 hour at room temperature. Nuclei were stained by 4',6-diamidino-2-phenylindole (DAPI) (Sigma). Images were taken by a Zeiss Axio Observer Z1 (Carl Zeiss) microscope.

Primary HCEnC were seeded in 8-well chamber slides (Nunc ${ }^{\mathrm{TM}}$ Lab-Tek $^{\mathrm{TM}}$ ) until confluency then fixed in 4\% PFA. 0.1\% Triton X-100 (Sigma Aldrich) for 5 minutes was applied to permeabilize the cells. Antibodies against CD73, CD166, Collagen I and IV, Na/K ATPase, ZO-1 and proliferation marker Ki-67 were used. The staining was proceeded following the steps described above. Images for the cell line were captured by a BX51 Olympus microscope (Olympus), while primary cells were shot by a confocal microscope, Nikon Ti-E (Volocity imaging software). ImageJ was used to analyze the pictures. [66]

\section{Surface carbohydrate staining}

HCEnC were cultured in 8-well chamber slides for lectin staining. FITC-conjugated lectins were used (Vector Labs) to visualize the surface carbohydrate distribution. The lectins were diluted in Lectin dilution buffer and applied for 30 minutes at $4^{\circ} \mathrm{C}$. Griffonia (bandeiraea) 
simplicifolia lectin I (GSL I) against galactose and $\mathrm{N}$-acteylgalactosamines, dolichos biflorus agglutinin (DBA), Peanut agglutuninin (PNA), Ricinus communis agglutinin I (RCA 120), Soybean agglutinin (SBA), Phaseolus vulgaris erythroagglutinin (PHA E) and Phaseolus vulgaris leucoagglutinin (PHA L) were used against galactose. Concanavalin A (CON A), Lens culinaris agglutinin (LCA) and Pisum sativum agglutinin (PSA) labelled mannose and glucose. Fucose and arabinose were stained by Ulex europaeus (UEA I) and Wheat germ agglutinin (WGA) and its succinylated form (sWGA) bound sialic acid. Hoechst 33342 stained the nuclei. All pictures were captured by an EVOS® FL microscope (Thermo Fisher Scientific).

\section{Statistical analysis}

One-Way ANOVA, student's t-test and Mann-Whitney U-tests were used to reveal statistical differences. P-values less than 0.05 ( $\mathrm{p}<0.05 * ; \mathrm{p}<0.01 * *$ ) were considered significant. 


\section{Results}

\section{Cell morphology and proliferation of CSCs}

CSC cultures were established by the enzymatic and explant method from the central and peripheral corneal stroma (Figure 3A). Cells from CD and PD were visible at plating proliferated fast and reached confluence in the course of 10-12 days, while CE and PE took 12-14 days to appear at the edges of explanted tissue, reaching confluence 20-25 days after isolation (Figure 3B). The 4 conditions displayed no morphologically apparent differences.

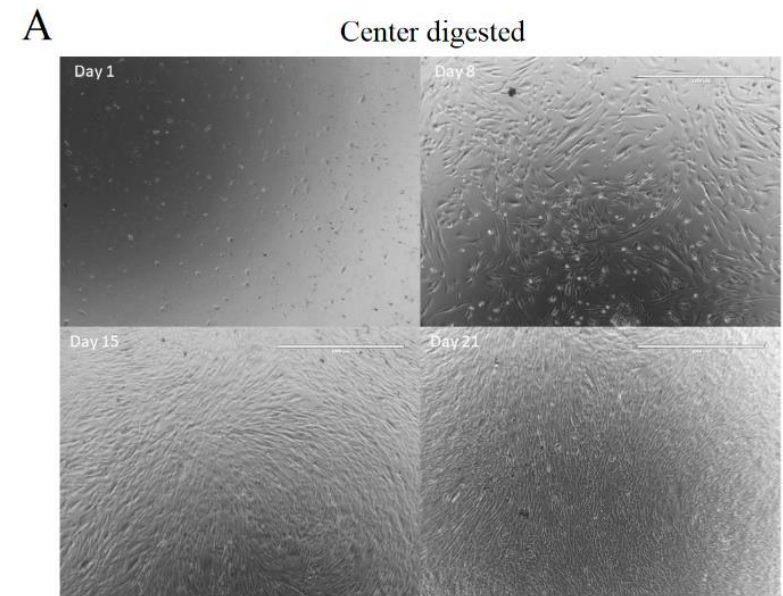

Periphery digested

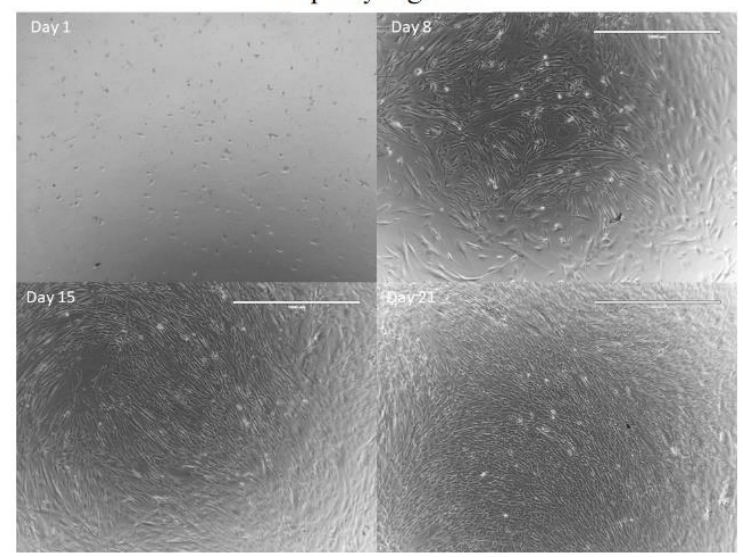

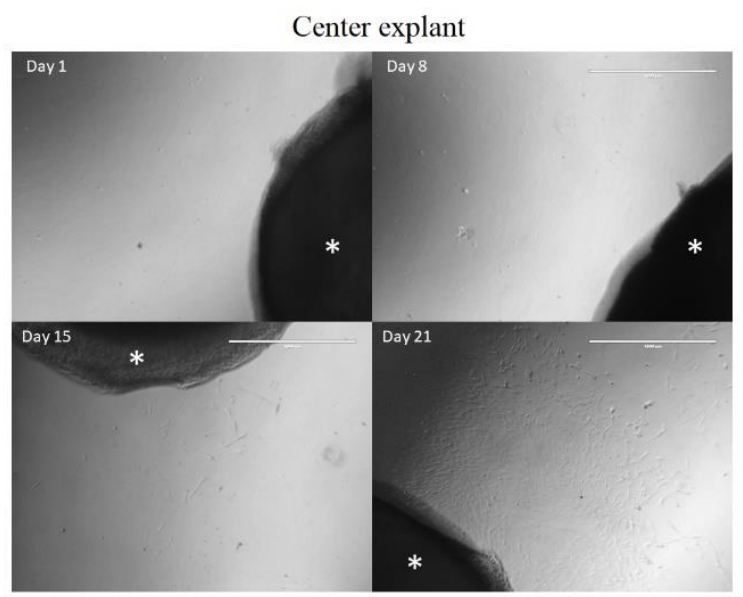

Periphery explant

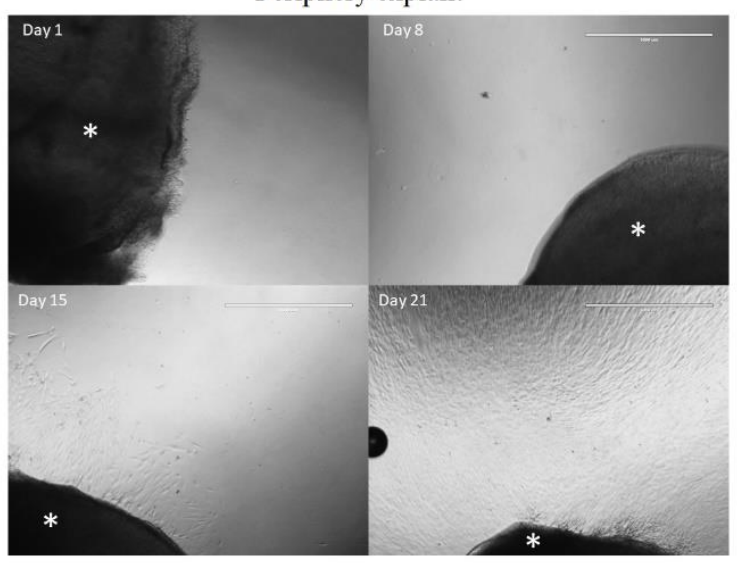

B

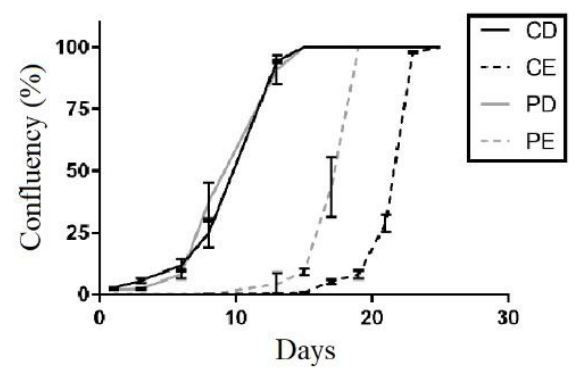


Figure 3. Phase contrast images showing CSC morphology and the growth rates of the various conditions. Pictures from day 1, 8, 15 and 21 of cultivation of the different CSCs are shown for the different conditions (A). The scale bar represents $1000 \mu \mathrm{m}$. Stromal explants are marked by an asterix (*). Confluency of the cells $\% \pm \mathrm{SD}(\mathrm{n}=3)$ was calculated using ImageJ software and the data was plotted accordingly for the days shown (B). (Continued from page 29)

All cultures showed Ki-67 positivity (Figure 4.) From all stained cells, $4.21 \pm 1.53 \%$, $7.87 \pm 4.73 \%, 8.60 \pm 4.58 \%$ and $10.95 \pm 4.42 \%$ demonstrated Ki-67 expression (Figure 4B) for $\mathrm{CD}, \mathrm{CE}, \mathrm{PD}$ and $\mathrm{PE}$, respectively. $(\mathrm{p}=0.43)$

A

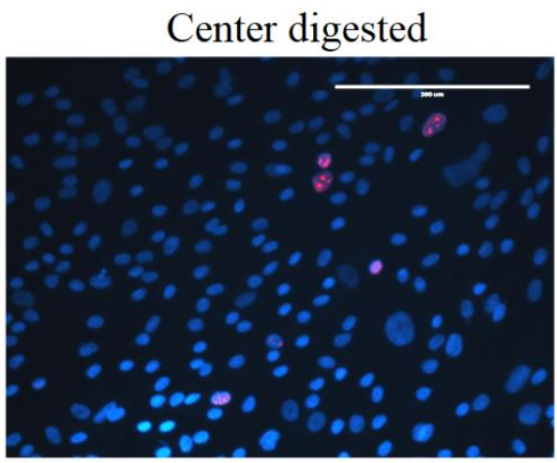

Periphery digested

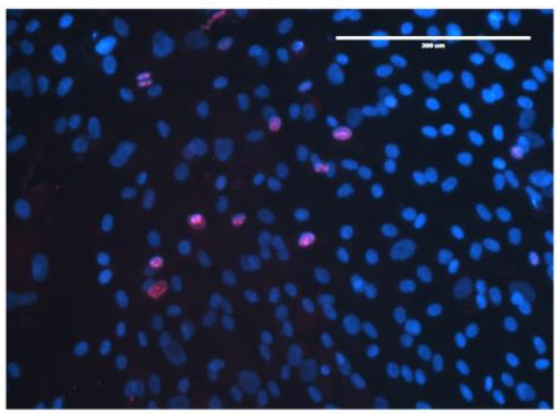

$\mathrm{B}$

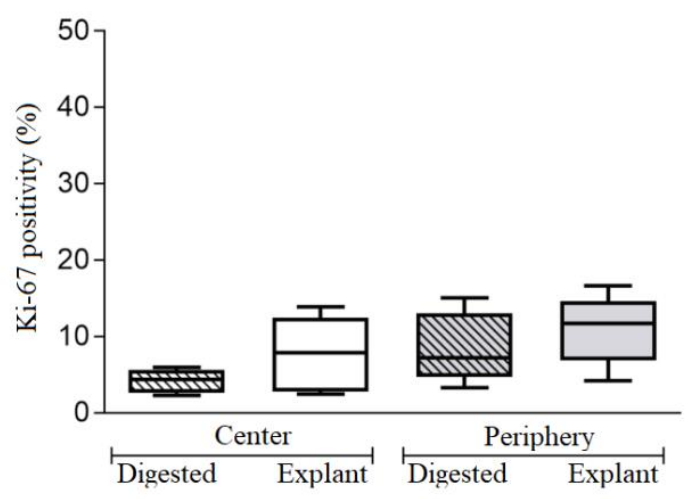

Figure 4. Ki-67 expression in cultured CSCs. Cells were cultured for 30 days and stained for nuclear Ki-67 (red) with DAPI counterstaining in blue (A). Relative quantity of positive cells (\%) \pm SD is shown $(\mathbf{B}) .(\mathrm{p}=0.43)$ The scale bars represent $200 \mu \mathrm{m}$. 


\section{Immunofluorescent staining of the native corneal stroma}

ABCG2 and ABCG5 could not be detected in the native cornea, while strong staining was observed for ALDH1A1, $\alpha$-actinin, CD31 and CD34 all over the stroma. Collagen I demonstrated a marked expression in the stroma, as well, while Collagen IV was not detected. CD73, CD90 and CD105, MSC markers were not present. Ki-67, CXCR4 and nestin were negative in the native tissue, as well. Vimentin was found to be expressed, while fibronectin was absent. No expression of other markers, such as anti-reticulocyte, fibroblast marker and VE-cadherin was detected in the native tissue (Figure 5 and Table 1). 


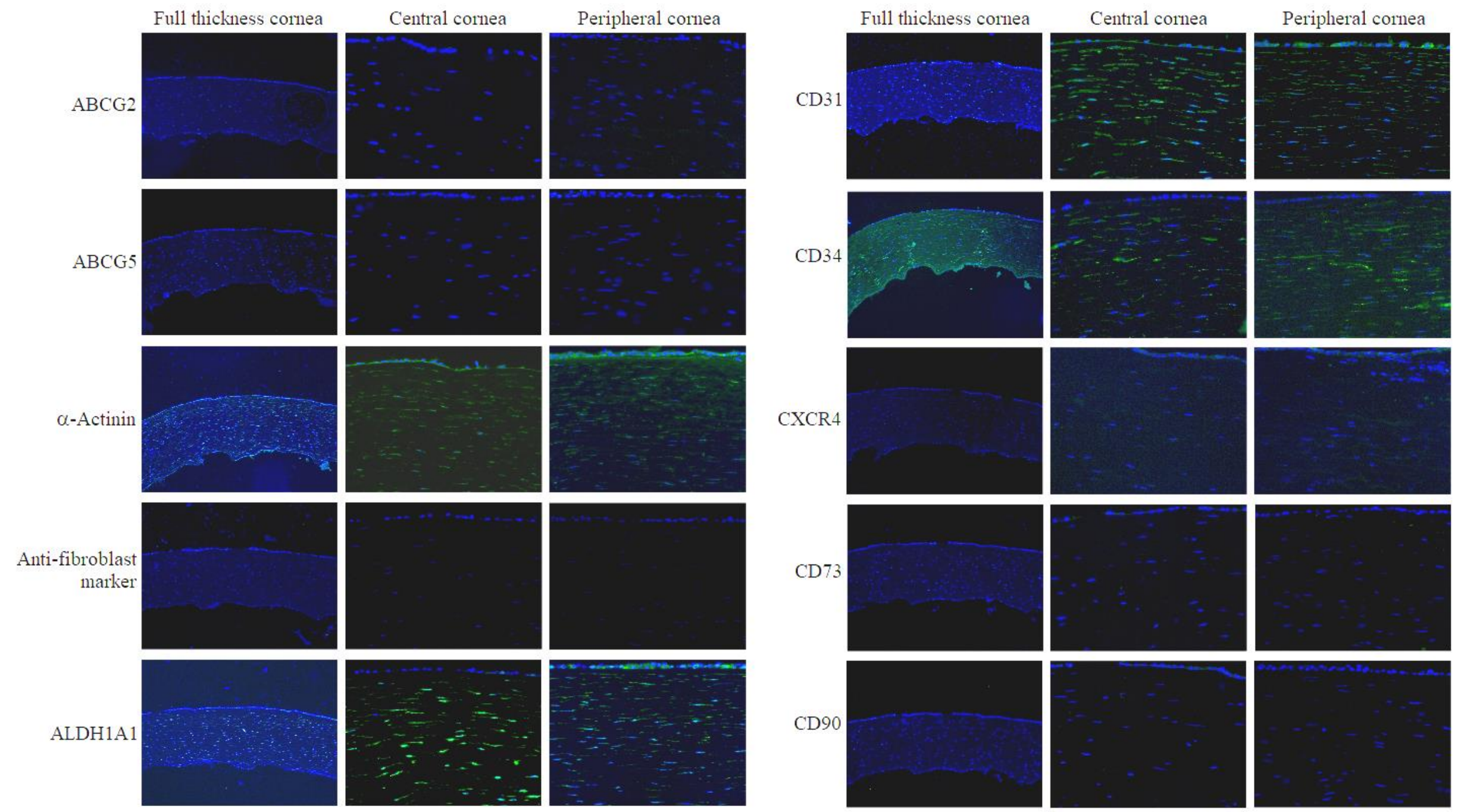

Figure 5. Fluorescent immunostaining of whole mount corneal sections. Pictures at 10x and 40x (left and right columns, respectively) magnifications were taken. Alexa Fluor 488 (green channel) was used to detected the presence of primary antibodies. Nuclei are shown in blue (DAPI). 


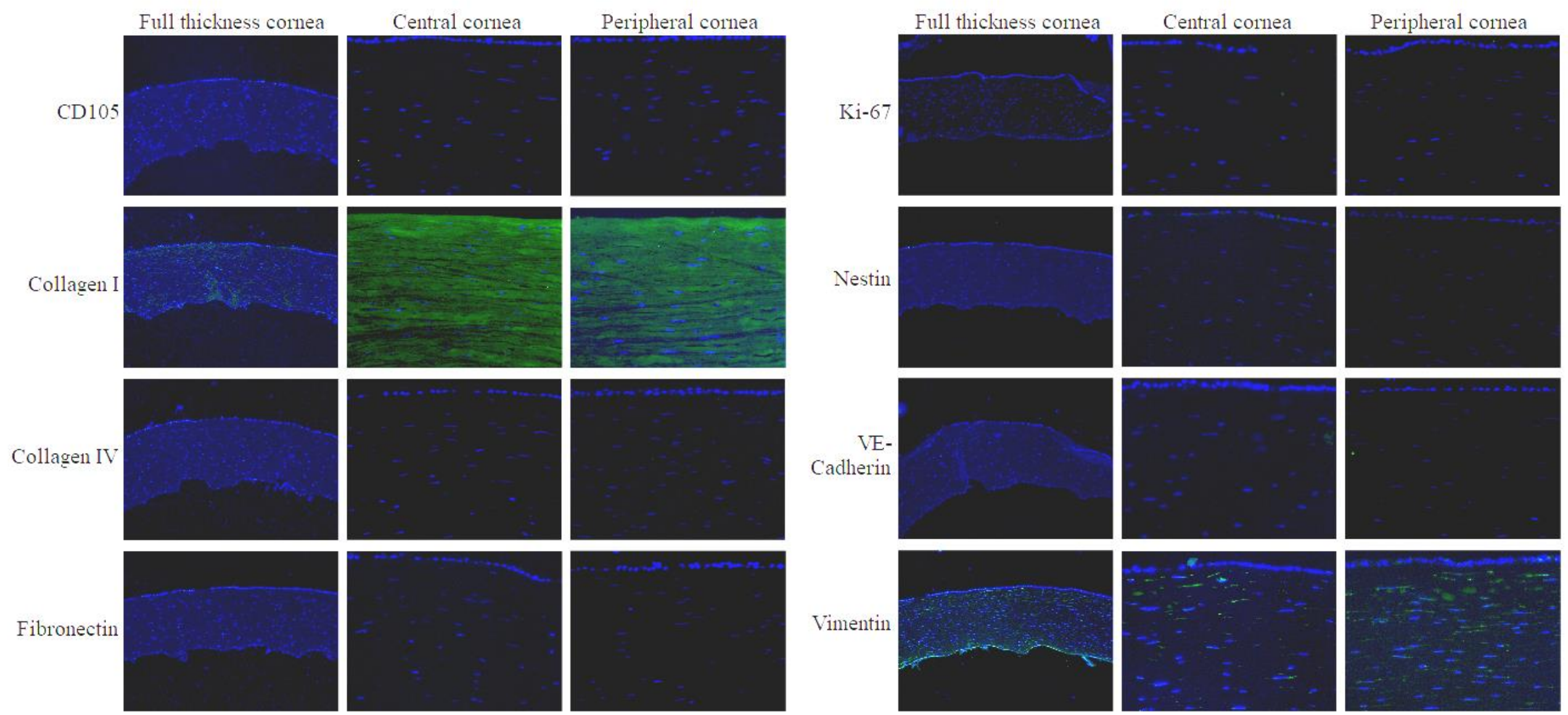

Figure 5. Fluorescent immunostaining of whole mount corneal sections. Pictures at 10x and 40x (left and right columns, respectively) magnifications were taken. Alexa Fluor 488 (green channel) was used to detected the presence of primary antibodies. Nuclei are shown in blue (DAPI). (Continued from page 32) 


\begin{tabular}{|c|c|c|c|c|}
\hline Marker & $\begin{array}{c}\text { Peripheral } \\
\text { stroma }\end{array}$ & $\begin{array}{c}\text { Central } \\
\text { stroma }\end{array}$ & $\begin{array}{c}\text { Anterior } \\
\text { stroma }\end{array}$ & $\begin{array}{c}\text { Posterior } \\
\text { stroma }\end{array}$ \\
\hline ABCG2 & - & - & - & - \\
\hline ABCG5 & + & + & + & + \\
\hline ALDH1A1 & ++ & ++ & ++ & + \\
\hline$\alpha$-Actinin & ++ & ++ & ++ & + \\
\hline CD31 & + & + & + & + \\
\hline CD34 & ++ & ++ & ++ & - \\
\hline CD73 & - & - & - & - \\
\hline CD90 & - & - & - & - \\
\hline CD105 & - & - & - & ++ \\
\hline Collagen I & ++ & ++ & ++ & - \\
\hline Collagen IV & - & - & - & - \\
\hline CXCR4 & - & - & - & - \\
\hline Fibroblast & - & - & - & - \\
\hline Fibronectin & - & - & - & - \\
\hline Ki-67 & - & - & - & - \\
\hline Nestin & - & - & - & ++ \\
\hline VE-Cadherin & - & - & - & ++ \\
\hline Vimentin & ++ & ++ & ++ & \\
\hline
\end{tabular}

Table 1. Panel of markers stained in the native tissue and respective signal strength in the various regions. ('-' not detected;'+' medium signal intensity;'++' strong signal intensity).

\section{FACS analysis of cultured CSCs}

High expression of CD73, CD90 and CD105 was detected in cultured CSCs, with no difference between the 4 groups. ABCG2 and Nestin, were detected, as well, while CD34 and CD31 were not present on any of the cultured cells (Figure 6). CD51, CD49a, CD49d adhesion molecules and integrin-related CD47 were positively expressed, with no significant difference between the different conditions. 

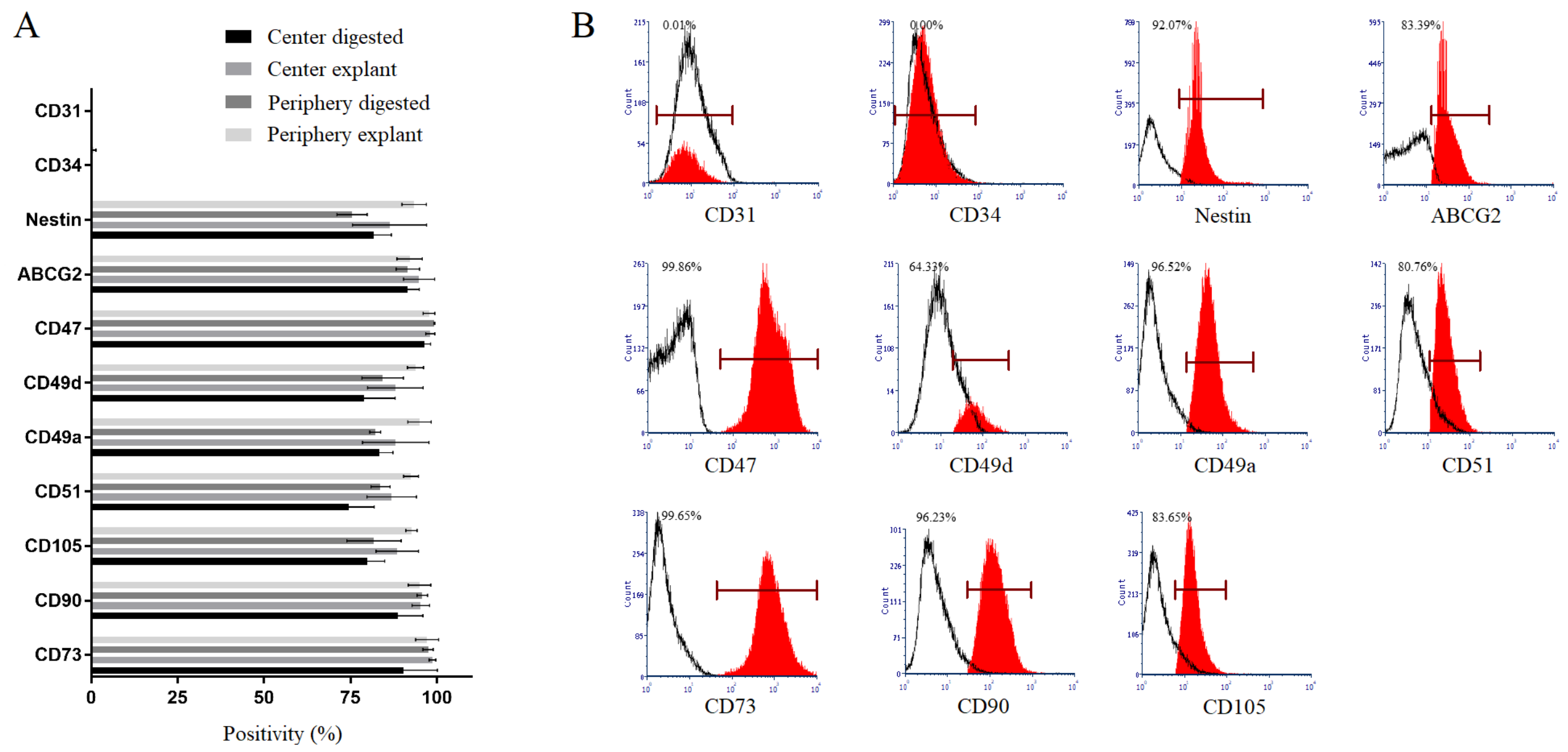

Figure 6. Markers expressed by cultured CSCs. Percentage of positive cells for the different surface-expressed markers \pm SD are shown (A) ( $n=3)$. The histograms show a representative PE donor $(\mathbf{B})$. The isotype control is shown in white color with the antibody in red, after Overton subtraction. 


\section{Gene expression in the native- versus cultured cells of the corneal stroma}

RT-qPCR revealed that CD73, CD90 and CD105 were upregulated in cultured CSCs, compared to the native tissue (by 14-, 95- and 25-fold; $\mathrm{p}=0.01, \mathrm{p}<0.01, \mathrm{p}<0.01$, respectively). Vimentin was upregulated in cultured cells, as well, 18-fold higher compared to the same control $(\mathrm{p}<0.01)$.

CD34 was significantly downregulated (5-fold) in the cultured cells when compared to the cells from the native tissue $(\mathrm{p}<0.01)$. Similarly, CD31 was significantly downregulated in the cultured cells. $(\mathrm{p}<0.01)$. ALDH1A1 was detected in the cultured cells with a significant downregulation compared to the native tissue $(\mathrm{p}<0.01)$ (Figure 7).

\section{- Native stroma \\ Cultured CSCs}

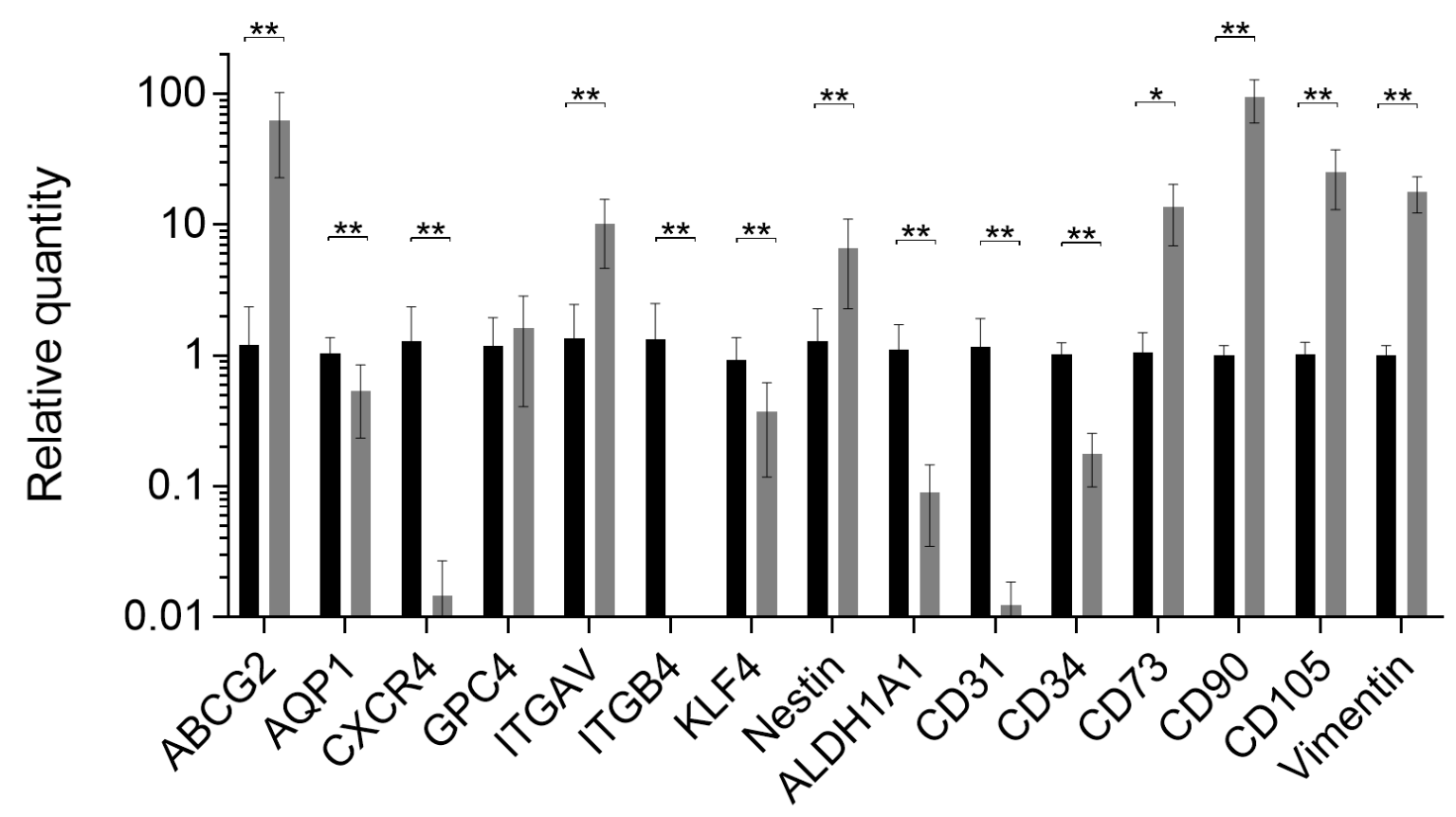

Figure 7. Relative gene expression levels in native versus cultured cornea stromal cells. Results were plot on a logarithmic scale. Relative detected quantities are shown with \pm standard deviation (SD). 18S RNA was used as an endogenous control gene in the experiments $(n=3)$.

Expression of ABCG2 was upregulated 60 -fold $(\mathrm{p}<0.01)$, while significantly lower expressions of AQP1, CXCR4, ITGB4 and KLF4 were observed in cultured CSCs ( $\mathrm{p}<0.01$, $\mathrm{p}<0.01, \mathrm{p}<0.01$ and $\mathrm{p}<0,01$, respectively). Expression of ITGAV and Nestin were 
upregulated in the cultured cells $(\mathrm{p}<0.01, \mathrm{p}<0.01)$, while GPC4 expression was unaltered $(\mathrm{p}=0.36)$.

\section{Comparison of the gene expression of B4G12 and primary HCEnC to CSCs}

RT-qPCR was used to analyze the relative gene expression of primary HCEnC and B4G12 (Figure 8). GAPDH was used as a reference gene and corresponding expression levels were normalized to that of the CSCs. The cell line (B4G12) demonstrated a 15-fold lower expression of Vimentin than the CSCs. CD90 expression was 13-fold higher, while cytokeratin-19 was 3-fold more expressed in CSCs compared to the cell line. Zonula occludens (ZO-1) and Claudin 14 were more expressed in B4G12: 2.2-fold and 10-fold, respectively, when compared to CSCs. Similar to the cell line, primary HCEnCs demonstrated a lower expression of Vimentin, as much as 3.1-fold, compared to the CSCs. Expression of CD90 was 3.2-fold lower in primary HCEnCs, while cytokeratin-19 was 7-fold lower than in CSCs. ZO-1 was 4.5-fold more expressed in HCEnCs.

A
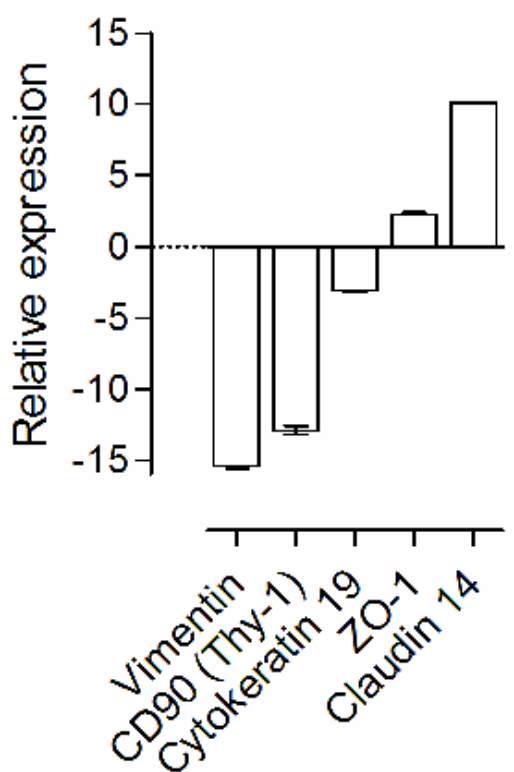

B
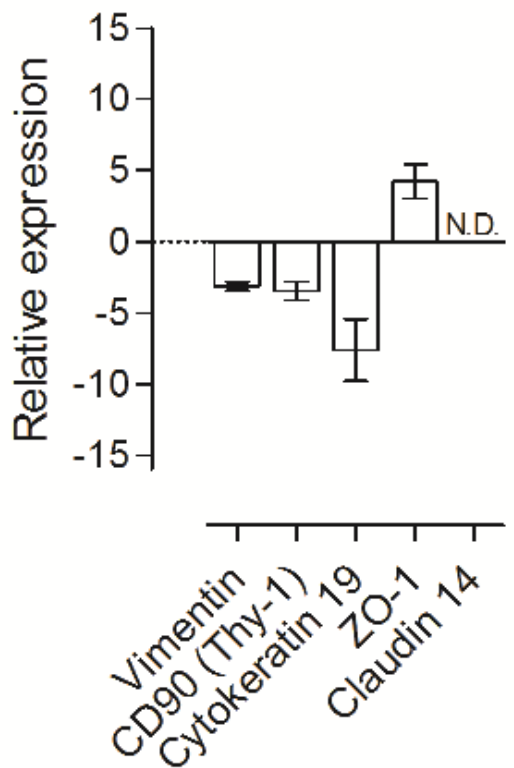

Figure 8. Expression of different genes in the B4G12 cell line (part A) and primary HCEnC (part B), normalized to CSCs. GAPDH was used as a reference gene is determining the gene expression of Vimentin, CD90, Cytokeratin-19, ZO-1 and Claudin 14, then results were normalized to those obtained for CSCs. Expression levels \pm SD are shown $(n=3)$. 


\section{Surface protein staining of HCEnCs}

A moderate expression of CD73 was found in the cytoplasm of primary HCEnCs (Figure 9A). CD166 was positive (Figure 9B.) as well and mostly localized close to the cell membrane, as the HCEnCs were stretching towards each other to establish the cellular contact. $\mathrm{Na} / \mathrm{K}$-ATPase was positive (Figure 9C) as well and mostly expressed around the edges of the cells. Presence of ZO-1 was not detected in the cell junctions, but a dim signal was observed in the cytoplasm (Figure 9D). Interestingly, staining for Collagen I and Collagen IV revealed the presence of the proteins in the cytoplasm of the cells (Figure 9E $\&$ F). Certain primary cells demonstrated the expression of nuclear Ki-67 (Figure 8G \& H). 


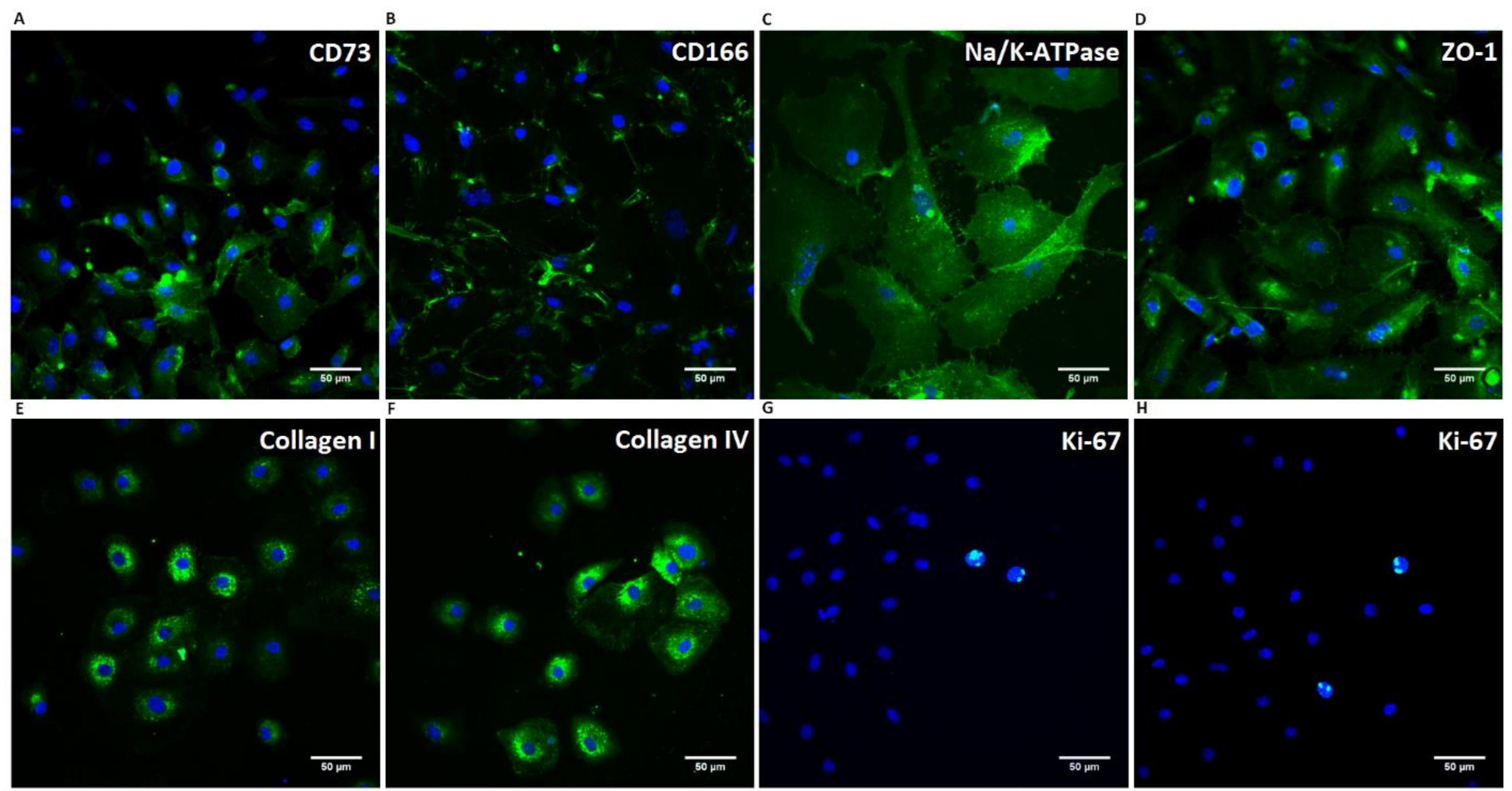

Figure 9. Surface protein expression on primary HCEnCs. FITC-conjugated secondary antibodies were used to detect CD73, CD166, ZO-1, Na/KATPase, Collagen I, Collagen IV and Ki-67, all shown in green. Cell nuclei were stained by DAPI (blue) (white bar $=50 \mu \mathrm{m}$ ). 
FACS analysis was used to compare the expression of certain markers that have been previously described in context with HCEnCs. Primary cells were freshly isolated and stained without further cultivation to serve as controls. Cultured HCEnCs demonstrated a high expression of CD73 (89.32 $\pm 1.35 \%)$, while $16.34 \pm 23.74 \%$ of uncultured cells showed a positive expression $(\mathrm{p}<0.001)$ (Table 2). Expression of CD90 was negative or low $(7.16 \pm 4.46 \%)$ in primary HCEnCs and a similar trend was observed in uncultured cells, as well $(8.56 \pm 13.26 \%, \mathrm{p}=0.768) .49 .52 \pm 17.26 \%$ of cultured HCEnCs expressed CD105. Most cultured HCEnCs expressed CD44 (68.39 $13.13 \%)$, while it's expression was significantly lower in uncultured cells $(6.68 \pm 2.44 \%$; $<<0.05)$. CD47 was present on the majority of cultured cells $(89.12 \pm 1.92 \%)$, while CD34 was not detected $(0.13 \pm 0.13 \%)$. High expression of CD54 was observed $(54.33 \pm 8.03 \%)$ and CD106 was expressed, as well $(38.08 \pm 15.23 \%)$, with a high inter-donor variability on cultured cells. $43.02 \pm 15.53 \%$ of primary cultured cells expressed CD146, while uncultured HCEnCs demonstrated a lower expression of the protein $(1.1 \pm 3.15 \%)(\mathrm{p}=0.404)$. Cultured HCEnCs demonstrated CD112 expression $(77.73 \pm 2.17 \%)$, with two separate populations, both being positive. A low expression of CD166 was observed in uncultured cells $(20.20 \pm 11.47 \%)$, while it was found to be increased in cultured HCEnCs $(78.93 \pm 1.69 \%)(\mathrm{p}=0.001)$. Similar to CD112, staining for CD325 showed two distinct populations of cultured cells $76.39 \pm 5.68 \%$. Uncultured HCEnCs also expressed CD325 $(69.61 \pm 7.08 \%)(\mathrm{p}=0.678)$.

\begin{tabular}{|c|c|c|}
\hline Surface marker & Primary HCEnC & Uncultured HCEnC \\
\hline CD34 & $0.13 \pm 0.13$ & n.m. \\
\hline CD44 & $68.39 \pm 13.13$ & $6.68 \pm 1.41$ \\
\hline CD47 & $89.12 \pm 1.92$ & n.m. \\
\hline CD54 & $54.33 \pm 8.03$ & n.m. \\
\hline CD73 & $89.32 \pm 1.35$ & $16.35 \pm 13.70$ \\
\hline CD90 & $7.16 \pm 4.46$ & $8.56 \pm 7.66$ \\
\hline CD105 & $49.52 \pm 17.26$ & n.m. \\
\hline CD106 & $38.08 \pm 15.23$ & n.m. \\
\hline CD112 & $77.73 \pm 2.17$ & n.m. \\
\hline CD146 & $43.02 \pm 15.53$ & $1.10 \pm 1.82$ \\
\hline CD166 & $78.93 \pm 1.69$ & $20.20 \pm 6.62$ \\
\hline CD325 & $76.39 \pm 5.68$ & $69.61 \pm 4.09$ \\
\hline
\end{tabular}


Table 2. Surface markers of primary, cultured- and uncultured HCEnCs. Percentage of positive cells (average \pm SEM) are shown. (n.m. : not measured) (Continued from page 40)

Hierarchical clustering of the data from cultured HCEnCs and CSCs demonstrated a difference in the phenotype of the two cell types. HCEnCs showed a high inter-donor variance, although the analysis clearly represented HCEnCs versus CSCs as two distinct cell types, based on their surface phenotype (Figure 10).

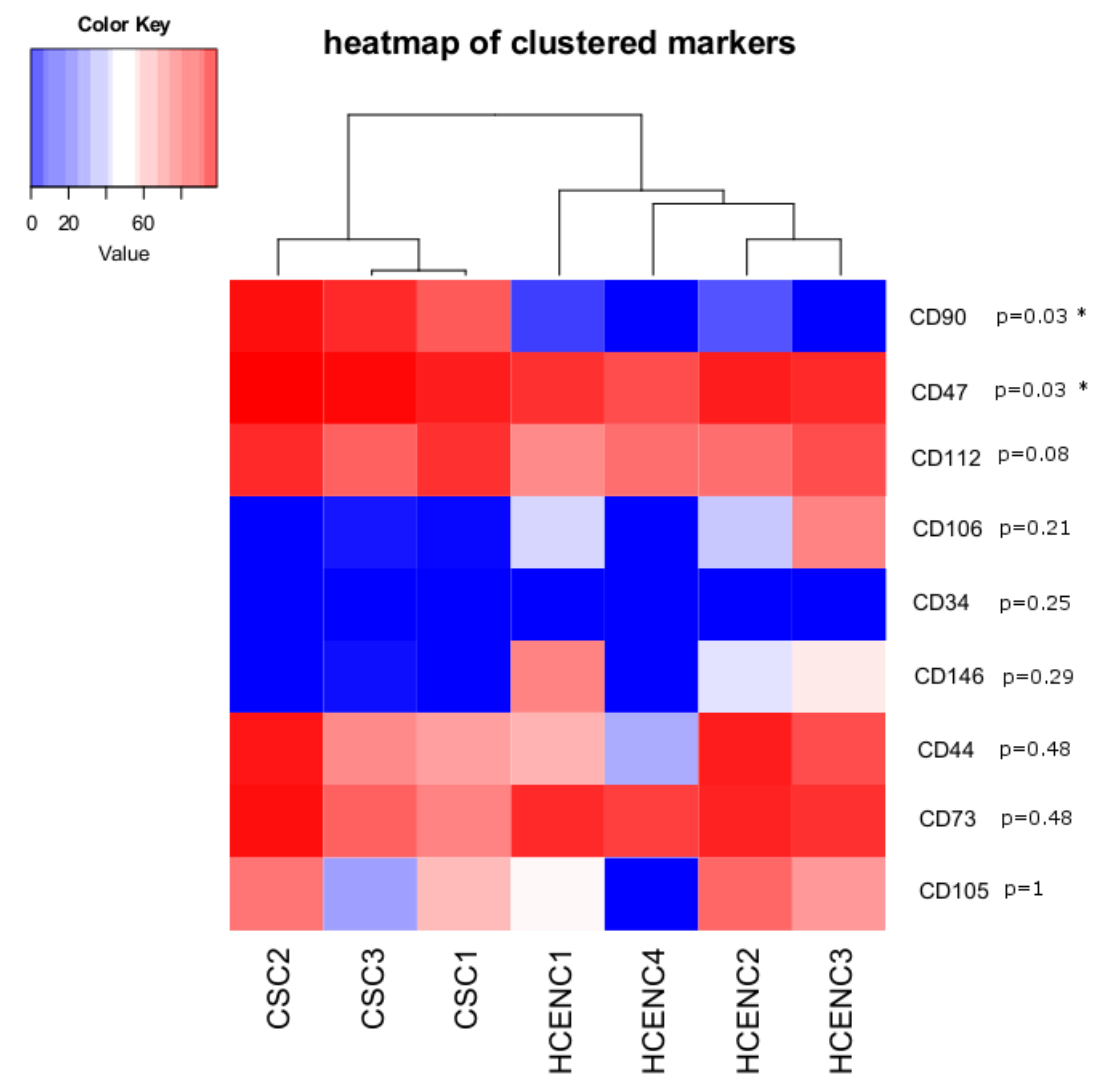

Figure 10. Heatmap analysis of the surface protein expression of HCEnCs and CSCs. Two clusters of data were formed by the software, as the results from HCEnCs (4 donors) and CSCs (3 donors) were analysed. Percentage of positive cells are shown and represented on the figure (0-100\%) with the respective p-values.

\section{Surface lectin-carbohydrate pattern of primary HCEnCs}

Primary HCEnCs were stained with FITC-conjugated lectins to reveal surface carbohydrates (Figure 11). The cells expressed terminal galactose molecules, confirmed by Ricinus communis agglutinin I (RCA). Complex galactose structures were detected by Phaseolus vulgaris leucoagglutinin (PHA L). Succinylated and non-succinylated Wheat germ agglutinin 
(sWGA, WGA) were positive for HCEnCs, binding to dimer and trimer $\mathrm{N}$ acetylgalactosamines. Mannose and D-glucose monomers and polymers were recognized by Lens culinaris agglutinin (LCA), Phaseolus vulgaris erythroagglutinin (PHA E), Pisum sativum agglutinin (PSA) and Concanavalin A (CON A).

Lectins Dolichos biflorus agglutinin (DBA), Soybean agglutinin (SBA), Griffonia (bandeiraea) simplicifolia lectin I (GSL I) did not show any $\mathrm{N}$-acetylgalactosamine monomers on the surface of HCEnCs. Presence of putative epithelial/endothelial marker Lfucose was not detected by Ulex europaeus (UEA I) and Peanut agglutinin (PNA) staining the T-antigen was negative on HCEnCs, as well.

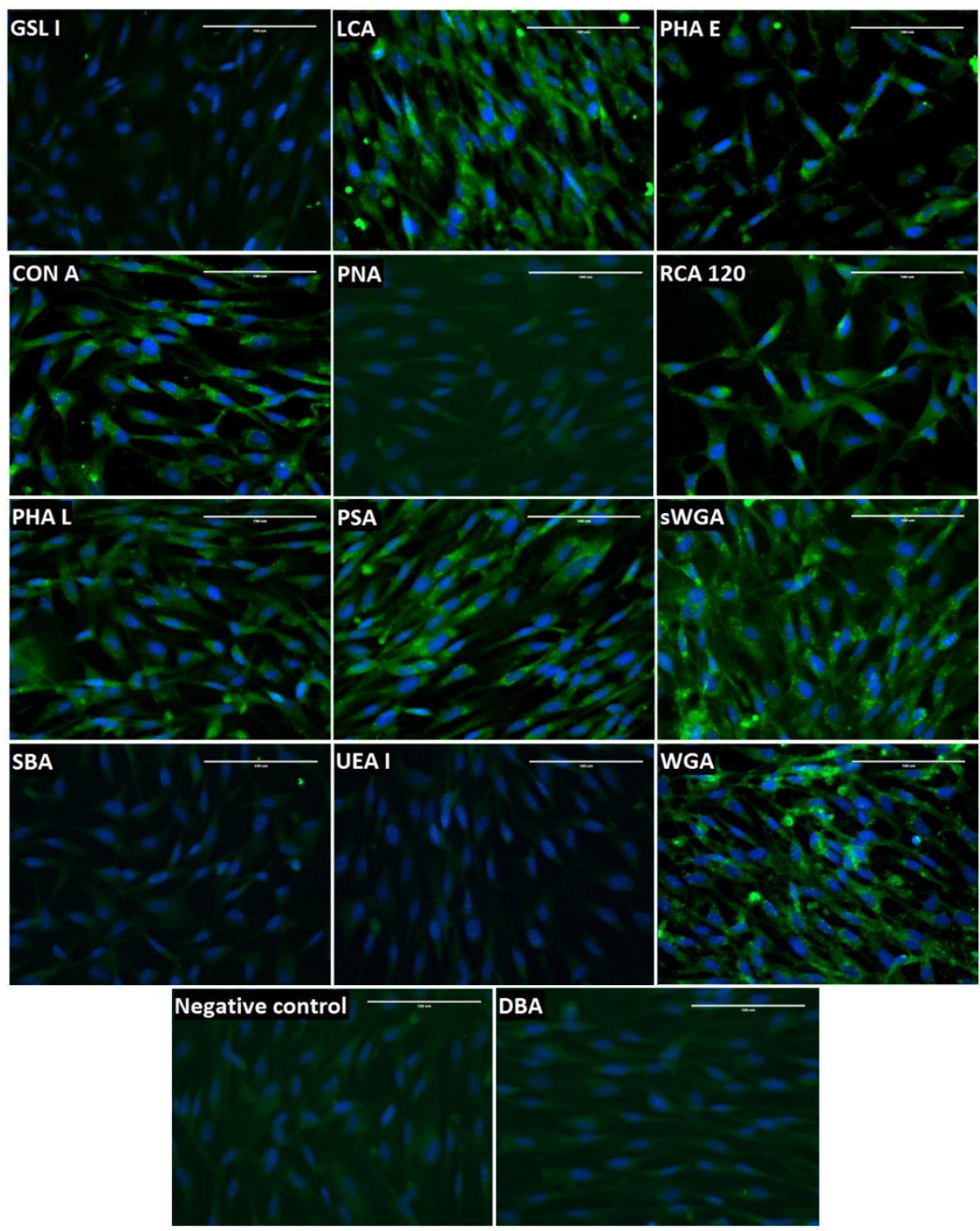

Figure 11. Lectin staining of primary HCEnCs. Surface carbohydrates were recognized by FITCconjugated lectins (green), with nuclei stained by Hoechst 33342 (white bar $=100 \mu \mathrm{m}$ ). 


\section{HCEnC viability}

$81.84 \pm 11.44 \%$ of cultured cells was viable, with a considerable number of necrotic cells $(26.55 \pm 15.79 \%)$, stained by propidium iodide (PI). $4.27 \pm 5.94 \%$ was the percentage of apoptotic cells (Annexin V FITC), while $5.5 \pm 4.23 \%$ of HCEnCs showed signs of secondary necrotic/late apoptotic state, confirmed by the double-stained cells. Similarly, trypan blue exclusion test showed an overall $80.01 \pm 11.92 \%$ viability in HCEnC cultures (Figure 12).

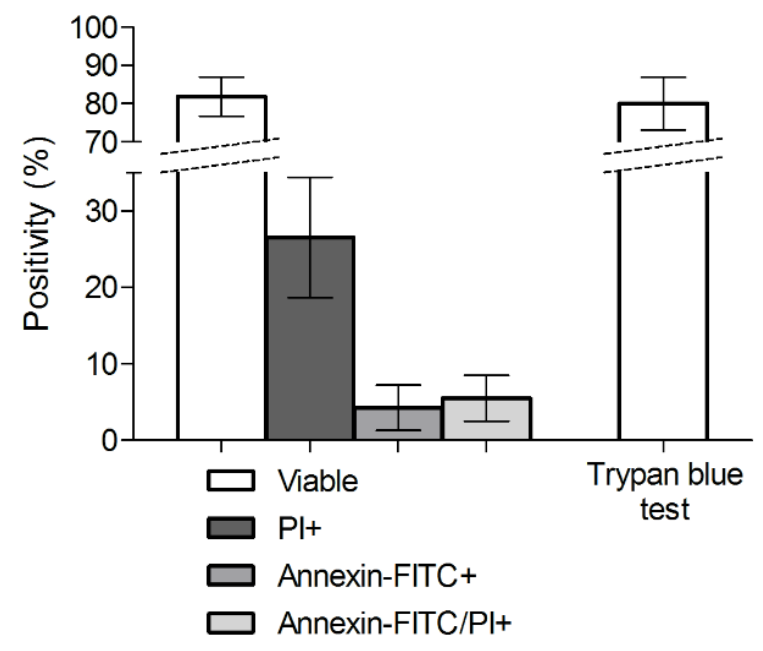

Figure 12. Viability of HCEnC cultures. Propidium iodide (PI) and annexin V were used to stain necrotic and apoptotic cells, respectively. Fluorescent intensities were measured by flow cytometry, data on the graphs is represented by 3 independent measurements of 2 donors. Mean \pm SD are shown of cultures aging 30 days. Trypan blue test shows an average of 4 measurements (mean \pm SD). 


\section{Discussion}

The world is facing a shortage of donors for corneal transplantation. [5] Cell therapy could be a possible alternative and while the potential of stem cells from different origins has been demonstrated numerous times in animal models, their safe and efficient application in human reconstruction is further to be proven. Cells for drug testing, corneal research and potential cell therapy agents can be obtained from the human corneal stroma. [31, 67] Different countries and research groups have access to different parts of the cornea. Mostly, it is corneal rings after full thickness keratoplasties or lamellar procedures (DMEK or DSAEK) that are used for cell isolation. Others have access to the central parts of the cornea, as well. It is unknown, whether cells from the various sources generate different cell phenotypes. CSCs are able to replicate in vitro and have outstanding features that have been demonstrated by many research groups, including us. [25] Notably, the CSCs phenotype adheres to the criteria established by ISCT for MSCs and the cells are also capable of the canonical trilineage differentiation. Moreover, possible immunosuppressive properties can be attributed to CSCs, in vitro. [25] The characteristics mentioned above are only displayed by cultured and not by the resident stromal cells, in vivo. The origin of the cultured cells is thus debated, whether it is the stromal keratocytes that adapt to environmental changes or a small population of progenitor cells get activated in vitro.

Whole mount corneas have been stained for previously described markers. No difference in the expression of the different anatomical regions was found. Putative stem cell efflux marker, ABCG2, was not detected on native cells and neither was ABCG5, while the cultures obtained from the central or peripheral parts of the cornea by the two methods showed marked positivity (>90\%) for ABCG2. This was validated by RT-qPCR analysis as well. Upregulation of the protein might allow the cells to be more resilient to external stimuli (e.g. chemotherapy), as previously demonstrated by malignant cells. [68, 69] ABCG2 positive cells have been described in the human limbus as well. [70] Murine-origin stem cells have been shown to be actively effluxing a dye, which could be inhibited by verapamil. [71] Strong staining for ALDH1A1 was detected in the native cornea. This molecule is a corneal crystalline and its expression is responsible for the transparency of the tissue, as the lack of ALDH1A1 is accompanied by the haziness of the cornea. [72] Although equally present in both central and peripheral parts of the cornea in vivo, the expression of the gene was significantly downregulated in cultured CSCs as assessed by RT-qPCR. $\alpha$-actinin was 
detected throughout the cornea, including the keratocytes, thus this marker alone should not be used to exclude fibroblastic cells when assessing the purity of a culture. [73] Vascular endothelial marker CD31 is thought to be involved in leukocyte migration. It mediates the attraction and adhesion of polymorphonuclear cells in wound healing. [74] The native cornea elicited a considerable CD31 expression, although the role of the protein in a healthy, avascular tissue is yet to be elucidated. Moreover, the ex vivo cultured CSCs presented here lose CD31 according to surface phenotyping and this downregulation was supported by results from RT-qPCR, as well. Possibly the most important marker of stromal keratocytes is CD34. Often referred to as the marker of hematopoietic stem cells, it is likely to have a wider range of functions, most likely being involved in immunological events, such as eosinophil migration and mobility. [75] Studies on CSCs have shown the gradual loss of CD34, during ex vivo cultivation. $[67,76]$ Our results confirm this, the native cornea demonstrated a strong positivity, while cultured cells showed complete loss of the protein. The expression of the gene was significantly downregulated in cultured cells, when compared to the native tissue. Clarification on the functions of CD34 in the physiological tissue is therefore further needed. [67] An important molecule, aquaporin-1, is known to be involved in the migration of the stromal keratocytes during wound healing, in vivo. It was found to be downregulated in the cultured CSCs, while others reported it to be expressed in vitro, as well, in an animal model. [77] Markers of MSCs - CD73, CD90 and CD105, were not detected in the native tissue, however a strong staining was observed in the cultured CSCs. This was supported by gene expression analysis and adheres to findings of others. [35]. The appereance of the 3 mesenchymal markers and the loss of CD34 in culture is what makes the CSCs comply to the ISCT criteria. Adult MSCs of different origin have similar surface expression patterns. [7881] Again, like CD34, CD90 is known to be involved in a wide range of actions, such as cellular and matrix adhesion, fibrosis, inflammation and tumor growth. [82] Immunosuppressive properties of MSCs are attributed to CD73 [83] and cultured CSCs retain the markers over long cultivation times and many passages. [84]

CSCs in culture synthesize considerable amount of extracellular matrix de novo, mostly being Collagen I (Szabo et al, in press, Histol. Histopathology). The molecule is expressed abundantly in the native corneal stroma, as demonstrated by immunostaining, while Collagen IV could not be detected. The expression of integrin $\alpha \mathrm{V}$ (CD51) was upregulated in cultured cells, with a significant downregulation of Integrin $\beta 4$, compared to in situ. This change in the balance of adhesion molecules and matrix components highlights the CSCs potential in 
responding to environmental changes. Intact corneas do not express fibronectin in situ, but the molecule appears temporarily during corneal wound healing in the stroma and epithelium. [85] No sign of nuclear Ki-67 was detected in the native corneas, demonstrating a lack of damage and following cell proliferation. Cultured CSCs, however, did expressed this marker, highlighting the existence of actively proliferating cells in all the isolating and cultivation conditions presented herein. Putative mesenchymal marker, Vimentin was strongly expressed in the healthy corneal stroma. This is in line with the findings of others and knockdown studies have showed that the absence of the protein is associated with the formation of corneal haze and thus subsequent visual impairment. [86] Nestin, a marker of neural stem cells, was not present in the cells in situ. It is believed to be responsible for the organization and rearrangement of filaments in the cells, and was found to be expressed in murine spheroid cultures and a putative population was described in rabbit corneas as well. [87, 88] Upregulation of the gene was detected in cultured CSCs compared to the native corneas in our study. Tissues directly exposed to the outside world as barriers are known to express KLF4, which is an important marker associated with stemness. [89] Our results show a significant downregulation in the expression of the protein following isolation and cultivation. Similarly, a stem cell migratory marker, CXCR4 has been found to be expressed by MSCs of different origin and inhibition of the protein resulted in an incomplete migratory response to bone marrow [90] and its upregulation has been implicated in EMT and cancer cell invasion. [91] In the current study, CXCR4 expression was found to be negative in vivo, by immunostaining and cultured CSCs elicited significantly decreased levels of the functional protein, as well, compared to the native cells in our study, however possible roles of stemness markers KLF4 and CXCR4 in the cornea are not yet know.

CSCs adopt characteristics of MSCs during ex vivo cultivation, with a simultaneous downregulation of certain functional molecules- a matter to be addressed when using these cells for treatment. The potential of CSCs is unquestionable, with its beneficial effects demonstrated in several studies involving animals. Although cultivation can force these cells to a dramatic change as shown in this study, compromises must be made to be able to apply these cells for in vitro research, while not addressing them as corneal keratocytes. Most likely, there are several factors that contribute to the adoption of such a phenotype of the cells, including environmental changes or the presence of serum in the cultivation medium. The results of this study show that there are likely no phenotypic or genotypic differences between CSCs generated by different methods of isolation, from central or peripheral 
anatomical regions of the corneal stroma. The results also show a great plasticity of CSCs in response to external stimuli in culture and possibly in vivo, as well to counter wounding or inflammation. Whether this change is reversible and beneficial for the cells and thus could be safely used in human cell therapy in conditions affecting the eye or other organs is to be further researched.

Successful isolation and cultivation, as well as obtaining reproducible data has been a major challenge for the research on corneal endothelial cells over the last 3 decades. To date, there is no single consistent method for the ex vivo cultivation of functional HCEnCs. A recent study claimed to have established a method for the generation of viable HCEnCs in vitro. [92] Reportedly a putative stem cell population exists in the zone between the corneal endothelium and the trabecular meshwork that could produce confluent monolayer over 7 passages. [93] Although HCEnCs do not proliferate, in vivo, compensatory mechanisms have been described, in which DNA synthesis in the cells is upregulated, therefore, there is proliferation and migration near the damaged area taking up to 24-66 hours. [94-96] Recently, it was reported that corneal endothelial cells in situ can maintain their capacity to proliferate due to a possible arrest in G1 phase. [97] Conditioned medium from bone-marrow MSCs has been shown to enhance the proliferation of functional HCEnCs in vitro. [98] Another study uses a method with two media applied at different stages of cultivation. [65] All studies aim at generating a standard method for the isolation and expansion of HCEnCs to produce homogenous cultures of functional cells, with the implication of possible clinical use as an alternative to corneal transplantation. According to a pre-clinical trial, which included transplantation of HCEnCs spread on collagen I sheets, such procedure was found insufficient in monkeys, while another trial aimed at injecting HCEnC suspension in the front segment of the eye to treat patients. [63] In the present study, we applied a previously reported method to obtain the cells by an enzymatic method to generate HCEnC cultures and characterize the resulting cell population [60], then compare it to a commercially available corneal endothelial cell line, B4G12. While the cell line showed a relatively steady expansion, primary HCEnCs took up to 3-4 weeks to achieve confluency in small culture wells. This could be indicative of a homogenous cell population of HCEnCs, as cultures overtaken by quickly expanding fibroblasts or contaminating stromal cells are real concerns of the scientific community. [99] Also, it is belived that these cells undergo EMT, due to culturing over extended periods of time, suggested by apparent changes in morphology. Stromal cell contamination of primary HCEnC cultures is a concern, although data obtained 
from our RT-qPCR analyses showed a higher expression of certain genes related to cell-cell adhesion, cellular junction formation and HCEnCs demonstrated a different pattern of gene expression from CSCs. This supports that the cultures established in the present study are likely free of stromal cells. Vimentin is marker of mesenchymal cells and a putative marker of EMT, although it has been described in the native corneal endothelium [100, 101] and the stroma, as well. CSCs expressed more Vimentin, than the B4G12 cell line and primary HCEnCs, although the difference was larger for the cell line. Possibly, primary HCEnCs undergo EMT, while the cell line does not show such a change, however, the use of Vimentin alone to determine the presence of EMT is not sufficient. ZO-1, a crucial marker of functional and interconnected cells, was detected in primary HCEnCs and the cell line, both showing higher expression compared to CSCs. Claudin 14 was detected in CSCs and B4G12, with a higher expression in the cell line, although this is contradictory to the finding of others. [102] Claudin 14 was not expressed in cultured HCEnCs and this, on the other hand, corresponds to results from another study. [102] Cytokeratin 19 expression is characteristic of the limbal epithelium and conjunctiva [103] and was found to exhibit low expression in HCEnCs and B4G12 compared to CSCs. These results indicate that while primary cells and the endothelial cell line express genes in a similar manner, the magnitude of expression differs and thus cannot be considered a great representation of each other. A study comparing the transcriptome of B4G12 versus primary cells found that the latter is more comparable to the gene expression observed in vivo. [58]

A recently reported panel for the surface marker expression of functional HCEnCs

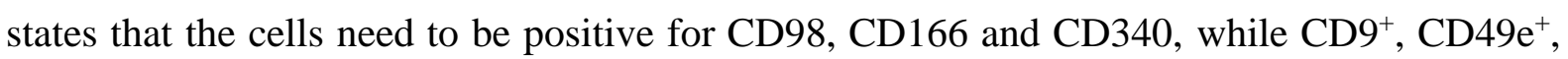
$\mathrm{CD}_{4}{ }^{+}$and $\mathrm{CD}^{+} 3^{+}$are non-functional, post-EMT cells. [62] FACS analysis revealed that the primary HCEnCs included in this study expressed CD44, CD73 and CD166. Epithelial cells with a damaged integrity to the layer are known to upregulate CD44 [104], and its expression was found in other tissues of the body in highly proliferative cells. [105, 106] This phenomenon has also been described in the basal corneal epithelium and in CSCs [25], but not in the healthy corneal endothelium. Upregulation of CD44 expression has also been implicated in graft rejection, Fuchs dystrophy and bullous keratopathy, as well as diseases, in which tissue integrity is compromised or when an injury is to be compensated. [107] However, CD44 has not been detected in keratoconus, lattice and Meesmann dystrophies with intact, unaffected corneal endothelium. Understandably, when cells of a closely packed layer, such as the corneal endothelium become singlet cells during isolation, they will 
possibly try to re-establish interconnections, as well as survive in the new environment. The majority of cultured HCEnCs showed positivity for CD44 in this study, contrary to the initial lack of expression observed in freshly isolated HCEnCs. Over 95\% of cultured CSCs express CD73, CD90 and CD105 [25], and while most HCEnCs were positive for CD73 and CD105, very low positivity $(<10 \%)$ was observed for CD90. This was supported by data from freshly isolated HCEnCs. Consequently, it suggests, that the HCEnC cultures established in our study were likely free of stromal contamination. There are still no exclusive surface protein markers to identify HCEnCs, so we herein propose a more extensive surface characterization based on surface glycoproteins/carbohydrates to described the cells generated by the cultivation method used in the study.

Up- and downregulation of glycoproteins have been shown to be a compensatory mechanism in epithelial injuries. [108, 109] This role has been implicated in corneal epithelial cells as well, with the LESCs having a well-defined carbohydrate pattern. [19] Cultured HCEnCs showed a similar lectin staining as CSCs. [25] Corneal diseases have been known to cause an altered carbohydrate/glycoconjugate expression. [110-112] Mice with a mutation in the Pax-6 gene displayed impaired compensatory response to an in vitro simulated epithelial injury, when $\alpha-\mathrm{D}$-mannose, $\alpha$-D-glucose and $\beta-\mathrm{N}$-acetylglucosamine 14 glucose were blocked by WGA and Con A. [109] In situ lectin staining patterns of the corneal endothelium have been described previously in human and animal specimens and found WGA, Con A, RCA to be positive, while GSL I, SBA and UEAI were negative in healthy donors. [111, 113] In basal corneal epithelium, WGA, Con A, RCA, GSL I and PHA staining were reported, while Con A, PHA and PSA were positive for the Descemet's membrane. [114] Undamaged corneal endothelium demonstrated no binding of SBA, while positivity was observed around the edges of injured areas, eventually decreasing and disappearing over the course of 72 hours. [111] It was also shown, that SBA altered actin rearrangement by binding to a specific component, during wound-healing experiments. [115] This finding led to another set of experiments, in which the authors concluded, that the glycoprotein, bound by SBA is possibly involved in the restoration of cell interactions, as it was expressed by diseased or distressed cells trying to compensate the loss of layer integrity ex vivo. [116] Moreover, SBA binding was described in keratoconus as well, suggesting a fine balance of surface carbohydrates in the maintenance of corneal physiology. [117] No SBA binding was observed in this study on cultured primary HCEnCs, possibly explained by the change of environment and subsequent shift/ transformation of cell fate. 
Present work shows that a popular method for generating HCEnCs can produce cells expressing markers associated with the phenotype of corneal endothelial cells. While these cells are adapting to the new environment, they are possibly trying to restore the integrity of the layer they once represented. During cultivation however, the cells are likely to undergo EMT and lose certain important, functional molecules (ZO-1), while acquiring markers (CD44, CD73), that are not expressed, in situ. It remains a question, whether the functions can be safely restored with providing the original environment (i.e. reimplantation) without the use of agents altering cell functions, before applying them therapeutically in clinical practice. Future research with clinical relevance might use induced pluripotent stem cells to obtain homogenous cultures, with functional cells, until a standard method for the safe isolation and cultivation of these cells from cadaveric tissue is established and proven safe.

Results presented in this study have demonstrated, that primary cells obtained from the human corneal stroma and endothelium are capable of producing viable cultures, however the cells do not fully represent their original functional forms. Nonetheless, both cells types have good a potential to become candidates for possible future ocular clinical recontructives therapy, once their use is proven safe, beneficial and efficient. 


\section{Acknowledgement}

I would like to express my gratitude to the supervisor of my work as a $\mathrm{PhD}$ student, Prof. Dr. ${ }^{\circ}$ Goran Petrovski, for his guidance and support through my studies and research, as well as personal matters. He has provided me with many opportunities and has introduced me to many of the leading scientists in this curious field of research.

I am also very grateful to the head of the Department of Ophthalmology, Prof. Dr. Andrea Facskó for providing the instituational background for my studies, research and financial support.

I owe much gratitude towards my colleagues and friends for the motivational support to complete my studies, namely Dr. Luna Djirackor, Dr. Réka Albert, Natasha Josifovska, Dr. Dóra Szabó and Dr. Zoltán Veréb.

Last, but not least, I would like to express my appreciation to my parents and extended family for the patience, support and love they had given me, and for putting me on the tracks of life, so that I could study and become the man I am today. 


\section{References}

1. Michelacci, Y.M., Collagens and proteoglycans of the corneal extracellular matrix. Braz J Med Biol Res, 2003. 36(8): p. 1037-46.

2. Meek, K.M. and A.J. Quantock, The use of X-ray scattering techniques to determine corneal ultrastructure. Prog Retin Eye Res, 2001. 20(1): p. 95-137.

3. Dua, H.S., et al., Human corneal anatomy redefined: a novel pre-Descemet's layer (Dua's layer). Ophthalmology, 2013. 120(9): p. 1778-85.

4. Weblink, Facts about the cornea and corneal disease.

5. Gain, P., et al., Global Survey of Corneal Transplantation and Eye Banking. JAMA Ophthalmol, 2016. 134(2): p. 167-73.

6. Weblink, Cornea transplants: What to expect.

7. Lee, R., et al., Long-term Visual Outcomes and Complications of Boston Keratoprosthesis Type II Implantation. Ophthalmology, 2017. 124(1): p. 27-35.

8. De Miguel, M.P., et al., Immunosuppressive properties of mesenchymal stem cells: advances and applications. Curr Mol Med, 2012. 12(5): p. 574-91.

9. Han, Z., et al., The role of immunosuppression of mesenchymal stem cells in tissue repair and tumor growth. Cell Biosci, 2012. 2(1): p. 8.

10. Abumaree, M., et al., Immunosuppressive properties of mesenchymal stem cells. Stem Cell Rev, 2012. 8(2): p. 375-92.

11. Haddad, R. and F. Saldanha-Araujo, Mechanisms of T-cell immunosuppression by mesenchymal stromal cells: what do we know so far? Biomed Res Int, 2014. 2014: p. 216806.

12. Hayashi, Y., N. Watanabe, and Y. Ohashi, The "replacement hypothesis": corneal stem cell origin epithelia are replaced by limbal stem cell origin epithelia in mouse cornea during maturation. Cornea, 2012. 31 Suppl 1: p. S68-73.

13. Chang, C.Y., et al., Acute wound healing in the human central corneal epithelium appears to be independent of limbal stem cell influence. Invest Ophthalmol Vis Sci, 2008. 49(12): p. 5279-86.

14. Elisseeff, J., et al., Future perspectives for regenerative medicine in ophthalmology. Middle East Afr J Ophthalmol, 2013. 20(1): p. 38-45.

15. Dua, H.S. and A. Azuara-Blanco, Autologous limbal transplantation in patients with unilateral corneal stem cell deficiency. Br J Ophthalmol, 2000. 84(3): p. 273-8.

16. Solomon, A., et al., Long-term outcome of keratolimbal allograft with or without penetrating keratoplasty for total limbal stem cell deficiency. Ophthalmology, 2002. 109(6): p. 1159-66.

17. Gomes, J.A., et al., Amniotic membrane transplantation for partial and total limbal stem cell deficiency secondary to chemical burn. Ophthalmology, 2003. 110(3): p. 466-73.

18. Pellegrini, G., et al., Long-term restoration of damaged corneal surfaces with autologous cultivated corneal epithelium. Lancet, 1997. 349(9057): p. 990-3.

19. Albert, R., et al., Cultivation and characterization of cornea limbal epithelial stem cells on lens capsule in animal material-free medium. PLoS One, 2012. 7(10): p. e47187.

20. Brown, K.D., et al., Plasma polymer-coated contact lenses for the culture and transfer of corneal epithelial cells in the treatment of limbal stem cell deficiency. Tissue Eng Part A, 2014. 20(3-4): p. 646-55.

21. Haagdorens, M., et al., Limbal Stem Cell Deficiency: Current Treatment Options and Emerging Therapies. Stem Cells Int, 2016. 2016: p. 9798374. 
22. Weblink, Europe approves Holoclar ${ }^{\circledR}$, the first stem cell-based medicinal product

23. Funderburgh, J.L., M.M. Mann, and M.L. Funderburgh, Keratocyte phenotype mediates proteoglycan structure: a role for fibroblasts in corneal fibrosis. J Biol Chem, 2003. 278(46): p. 45629-37.

24. Helary, C., et al., Dense fibrillar collagen matrices: a model to study myofibroblast behaviour during wound healing. Biomaterials, 2006. 27(25): p. 4443-52.

25. Vereb, Z., et al., Role of Human Corneal Stroma-Derived Mesenchymal-Like Stem Cells in Corneal Immunity and Wound Healing. Sci Rep, 2016. 6: p. 26227.

26. Dominici, M., et al., Minimal criteria for defining multipotent mesenchymal stromal cells. The International Society for Cellular Therapy position statement. Cytotherapy, 2006. 8(4): p. 315-7.

27. Du, Y., et al., Multipotent stem cells in human corneal stroma. Stem Cells, 2005. 23(9): p. 1266-75.

28. Hashmani, K., et al., Characterization of corneal stromal stem cells with the potential for epithelial transdifferentiation. Stem Cell Res Ther, 2013. 4(3): p. 75.

29. Branch, M.J., et al., Mesenchymal stem cells in the human corneal limbal stroma. Invest Ophthalmol Vis Sci, 2012. 53(9): p. 5109-16.

30. Bray, L.J., et al., Immunosuppressive properties of mesenchymal stromal cell cultures derived from the limbus of human and rabbit corneas. Cytotherapy, 2014. 16(1): p. 64-73.

31. Pinnamaneni, N. and J.L. Funderburgh, Concise review: Stem cells in the corneal stroma. Stem Cells, 2012. 30(6): p. 1059-63.

32. Harkin, D.G., et al., Concise reviews: can mesenchymal stromal cells differentiate into corneal cells? A systematic review of published data. Stem Cells, 2015. 33(3): p. 785-91.

33. Choong, P.F., et al., Mesenchymal stromal cell-like characteristics of corneal keratocytes. Cytotherapy, 2007. 9(3): p. 252-8.

34. Sidney, L.E., et al., Effect of culture medium on propagation and phenotype of corneal stroma-derived stem cells. Cytotherapy, 2015. 17(12): p. 1706-22.

35. Sidney, L.E. and A. Hopkinson, Corneal keratocyte transition to mesenchymal stem cell phenotype and reversal using serum-free medium supplemented with FGF-2, TGF-ss3 and retinoic acid. J Tissue Eng Regen Med, 2016.

36. Guo, X., et al., Morphologic characterization of organized extracellular matrix deposition by ascorbic acid-stimulated human corneal fibroblasts. Invest Ophthalmol Vis Sci, 2007. 48(9): p. 4050-60.

37. Ren, R., et al., Human primary corneal fibroblasts synthesize and deposit proteoglycans in long-term 3-D cultures. Dev Dyn, 2008. 237(10): p. 2705-15.

38. Karamichos, D., A.E. Hutcheon, and J.D. Zieske, Transforming growth factor-beta3 regulates assembly of a non-fibrotic matrix in a $3 D$ corneal model. J Tissue Eng Regen Med, 2011. 5(8): p. e228-38.

39. de Araujo, A.L. and J.A. Gomes, Corneal stem cells and tissue engineering: Current advances and future perspectives. World J Stem Cells, 2015. 7(5): p. 806-14.

40. Wilson, S.L., et al., Keeping an eye on decellularized corneas: a review of methods, characterization and applications. J Funct Biomater, 2013. 4(3): p. 114-61.

41. Wu, J., et al., Corneal stromal stem cells versus corneal fibroblasts in generating structurally appropriate corneal stromal tissue. Exp Eye Res, 2014. 120: p. 71-81.

42. Zhang, L., et al., Mesenchymal stem cells for treating ocular surface diseases. BMC Ophthalmol, 2015. 15 Suppl 1: p. 155.

43. Yao, L. and H. Bai, Review: mesenchymal stem cells and corneal reconstruction. Mol Vis, 2013. 19: p. 2237-43. 
44. Du, Y., et al., Stem cell therapy restores transparency to defective murine corneas. Stem Cells, 2009. 27(7): p. 1635-42.

45. Choi, S.O., et al., Recovery of Corneal Endothelial Cells from Periphery after Injury. PLoS One, 2015. 10(9): p. e0138076.

46. Yu, W.Y., et al., Progenitors for the corneal endothelium and trabecular meshwork: a potential source for personalized stem cell therapy in corneal endothelial diseases and glaucoma. J Biomed Biotechnol, 2011. 2011: p. 412743.

47. Amann, J., et al., Increased endothelial cell density in the paracentral and peripheral regions of the human cornea. Am J Ophthalmol, 2003. 135(5): p. 584-90.

48. McGowan, S.L., et al., Stem cell markers in the human posterior limbus and corneal endothelium of unwounded and wounded corneas. Mol Vis, 2007. 13: p. 1984-2000.

49. Whikehart, D.R., et al., Evidence suggesting the existence of stem cells for the human corneal endothelium. Mol Vis, 2005. 11: p. 816-24.

50. Senoo, T. and N.C. Joyce, Cell cycle kinetics in corneal endothelium from old and young donors. Invest Ophthalmol Vis Sci, 2000. 41(3): p. 660-7.

51. Ding, V., et al., Generation of novel monoclonal antibodies for the enrichment and characterization of human corneal endothelial cells (hCENC) necessary for the treatment of corneal endothelial blindness. MAbs, 2014. 6(6): p. 1439-52.

52. Zhu, Y.T., et al., Engineering of Human Corneal Endothelial Grafts. Curr Ophthalmol Rep, 2015. 3(3): p. 207-217.

53. Wang, J., et al., Transforming growth factor-beta2 induces morphological alteration of human corneal endothelial cells in vitro. Int J Ophthalmol, 2014. 7(5): p. 759-63.

54. Riento, K. and A.J. Ridley, Rocks: multifunctional kinases in cell behaviour. Nat Rev Mol Cell Biol, 2003. 4(6): p. 446-56.

55. Pipparelli, A., et al., ROCK inhibitor enhances adhesion and wound healing of human corneal endothelial cells. PLoS One, 2013. 8(4): p. e62095.

56. Narumiya, S., The small GTPase Rho: cellular functions and signal transduction. J Biochem, 1996. 120(2): p. 215-28.

57. Amano, M., Y. Fukata, and K. Kaibuchi, Regulation and functions of Rho-associated kinase. Exp Cell Res, 2000. 261(1): p. 44-51.

58. Frausto, R.F., D.J. Le, and A.J. Aldave, Transcriptomic Analysis of Cultured Corneal Endothelial Cells as a Validation for Their Use in Cell-Replacement Therapy. Cell Transplant, 2015.

59. McCabe, K.L., et al., Efficient Generation of Human Embryonic Stem Cell-Derived Corneal Endothelial Cells by Directed Differentiation. PLoS One, 2015. 10(12): p. e0145266.

60. Parekh, M., et al., Concise Review: An Update on the Culture of Human Corneal Endothelial Cells for Transplantation. Stem Cells Transl Med, 2016. 5(2): p. 258-64.

61. Cheong, Y.K., et al., Identification of cell surface markers glypican-4 and CD200 that differentiate human corneal endothelium from stromal fibroblasts. Invest Ophthalmol Vis Sci, 2013. 54(7): p. 4538-47.

62. Okumura, N., et al., Cell surface markers of functional phenotypic corneal endothelial cells. Invest Ophthalmol Vis Sci, 2014. 55(11): p. 7610-8.

63. Kinoshita, S., Novel Treatment Dimensions for Corneal Endothelial Dysfunction, in American Society of Cataract and Refractive Surgery (ASCRS) 2016 Symposium. 2015: San Diego.

64. Chen, S., et al., Analysis of cell surface carbohydrate expression patterns in normal and tumorigenic human breast cell lines using lectin arrays. Anal Chem, 2007. 79(15): p. 5698-702. 
65. Peh, G.S., et al., Propagation of human corneal endothelial cells: a novel dual media approach. Cell Transplant, 2015. 24(2): p. 287-304.

66. Ginanneschi, F., et al., Changes in the recruitment curve of the soleus H-reflex associated with chronic low back pain. Clin Neurophysiol, 2007. 118(1): p. 111-8.

67. Sidney, L.E., et al., Concise review: evidence for CD34 as a common marker for diverse progenitors. Stem Cells, 2014. 32(6): p. 1380-9.

68. Natarajan, K., et al., Role of breast cancer resistance protein (BCRP/ABCG2) in cancer drug resistance. Biochem Pharmacol, 2012. 83(8): p. 1084-103.

69. Mao, Q. and J.D. Unadkat, Role of the breast cancer resistance protein (BCRP/ABCG2) in drug transport--an update. AAPS J, 2015. 17(1): p. 65-82.

70. Watanabe, K., et al., Human limbal epithelium contains side population cells expressing the ATP-binding cassette transporter ABCG2. FEBS Lett, 2004. 565(1-3): p. 6-10.

71. Goodell, M.A., et al., Isolation and functional properties of murine hematopoietic stem cells that are replicating in vivo. J Exp Med, 1996. 183(4): p. 1797-806.

72. Jester, J.V., et al., The cellular basis of corneal transparency: evidence for 'corneal crystallins'. J Cell Sci, 1999. 112 ( Pt 5): p. 613-22.

73. Bray, L.J., et al., Evaluation of methods for cultivating limbal mesenchymal stromal cells. Cytotherapy, 2012. 14(8): p. 936-47.

74. Burns, A.R., Z. Li, and C.W. Smith, Neutrophil migration in the wounded cornea: the role of the keratocyte. Ocul Surf, 2005. 3(4 Suppl): p. S173-6.

75. Nielsen, J.S. and K.M. McNagny, Novel functions of the CD34 family. J Cell Sci, 2008. 121(Pt 22): p. 3683-92.

76. Perrella, G., et al., Expression of haematopoietic stem cell markers, CD133 and CD34 on human corneal keratocytes. Br J Ophthalmol, 2007. 91(1): p. 94-9.

77. Ruiz-Ederra, J. and A.S. Verkman, Aquaporin-1-facilitated keratocyte migration in cell culture and in vivo corneal wound healing models. Exp Eye Res, 2009. 89(2): p. 159-65.

78. Maleki, M., et al., Comparison of mesenchymal stem cell markers in multiple human adult stem cells. Int J Stem Cells, 2014. 7(2): p. 118-26.

79. Aslan, H., et al., Osteogenic differentiation of noncultured immunoisolated bone marrow-derived CD105+ cells. Stem Cells, 2006. 24(7): p. 1728-37.

80. Lin, C.S., et al., Commonly used mesenchymal stem cell markers and tracking labels: Limitations and challenges. Histol Histopathol, 2013. 28(9): p. 1109-16.

81. Kozdon, K., et al., Mesenchymal Stem Cell-Like Properties of Orbital Fibroblasts in Graves' Orbitopathy. Invest Ophthalmol Vis Sci, 2015. 56(10): p. 5743-50.

82. Rege, T.A. and J.S. Hagood, Thy-1 as a regulator of cell-cell and cell-matrix interactions in axon regeneration, apoptosis, adhesion, migration, cancer, and fibrosis. FASEB J, 2006. 20(8): p. 1045-54.

83. Kerkela, E., et al., Adenosinergic Immunosuppression by Human Mesenchymal Stromal Cells Requires Co-Operation with T cells. Stem Cells, 2016. 34(3): p. 78190.

84. Okolicsanyi, R.K., et al., Human Mesenchymal Stem Cells Retain Multilineage Differentiation Capacity Including Neural Marker Expression after Extended In Vitro Expansion. PLoS One, 2015. 10(9): p. e0137255.

85. Fujikawa, L.S., et al., Fibronectin in healing rabbit corneal wounds. Lab Invest, 1981. 45(2): p. 120-9.

86. Das, S.K., et al., Vimentin knockdown decreases corneal opacity. Invest Ophthalmol Vis Sci, 2014. 55(7): p. 4030-40. 
87. Mimura, T., et al., Isolation and distribution of rabbit keratocyte precursors. Mol Vis, 2008. 14: p. 197-203.

88. Li, H., et al., Spheroid cultures promote the stemness of corneal stromal cells. Tissue Cell, 2015. 47(1): p. 39-48.

89. Segre, J.A., C. Bauer, and E. Fuchs, Klf4 is a transcription factor required for establishing the barrier function of the skin. Nat Genet, 1999. 22(4): p. 356-60.

90. Wynn, R.F., et al., A small proportion of mesenchymal stem cells strongly expresses functionally active CXCR4 receptor capable of promoting migration to bone marrow. Blood, 2004. 104(9): p. 2643-5.

91. Chatterjee, S., B. Behnam Azad, and S. Nimmagadda, The intricate role of CXCR4 in cancer. Adv Cancer Res, 2014. 124: p. 31-82.

92. Peh, G.S., et al., Cultivation of human corneal endothelial cells isolated from paired donor corneas. PLoS One, 2011. 6(12): p. e28310.

93. Walshe, J. and D.G. Harkin, Serial explant culture provides novel insights into the potential location and phenotype of corneal endothelial progenitor cells. Exp Eye Res, 2014. 127: p. 9-13.

94. Gordon, S.R. and H. Rothstein, Studies on corneal endothelial growth and repair. III. Effects of DNA and RNA synthesis inhibitors upon restoration of transparency following injury. Ophthalmic Res, 1982. 14(3): p. 195-209.

95. Gordon, S.R., H. Rothstein, and C.V. Harding, Studies on corneal endothelial growth and repair. IV. Changes in the surface during cell division as revealed by scanning electron microscopy. Eur J Cell Biol, 1983. 31(1): p. 26-33.

96. Rothstein, H. and S.R. Gordon, Studies on corneal endothelial growth and repair. II. increased transcription as detected by incorporation of $3 \mathrm{H}$-uridine and $3 \mathrm{H}$ actinomycin D. Tissue Cell, 1980. 12(4): p. 647-59.

97. Joyce, N.C., Proliferative capacity of corneal endothelial cells. Exp Eye Res, 2012. 95(1): p. 16-23.

98. Joyce, N.C., et al., Potential of human umbilical cord blood mesenchymal stem cells to heal damaged corneal endothelium. Mol Vis, 2012. 18: p. 547-64.

99. Peh, G.S., et al., Optimization of human corneal endothelial cells for culture: the removal of corneal stromal fibroblast contamination using magnetic cell separation. Int J Biomater, 2012. 2012: p. 601302.

100. Risen, L.A., P.S. Binder, and S.K. Nayak, Intermediate filaments and their organization in human corneal endothelium. Invest Ophthalmol Vis Sci, 1987. 28(12): p. 1933-8.

101. Feizi, S., et al., Effect of amniotic fluid on the in vitro culture of human corneal endothelial cells. Exp Eye Res, 2014. 122: p. 132-40.

102. Inagaki, E., et al., Expression and distribution of claudin subtypes in human corneal endothelium. Invest Ophthalmol Vis Sci, 2013. 54(12): p. 7258-65.

103. Auw-Haedrich, C., et al., Immunohistochemical expression of epithelial cell markers in corneas with congenital aniridia and ocular cicatrizing pemphigoid. Acta Ophthalmol, 2011. 89(1): p. 47-53.

104. Desai, V.D., et al., CD44 expression is developmentally regulated in the mouse lens and increases in the lens epithelium after injury. Differentiation, 2010. 79(2): p. 1119.

105. Alho, A.M. and C.B. Underhill, The hyaluronate receptor is preferentially expressed on proliferating epithelial cells. J Cell Biol, 1989. 108(4): p. 1557-65.

106. Abbasi, A.M., et al., CD44 is associated with proliferation in normal and neoplastic human colorectal epithelial cells. Eur J Cancer, 1993. 29A(14): p. 1995-2002. 
107. Zhu, S.N., B. Nolle, and G. Duncker, Expression of adhesion molecule CD44 on human corneas. Br J Ophthalmol, 1997. 81(1): p. 80-4.

108. Panjwani, N., S. Ahmad, and M.B. Raizman, Cell surface glycoproteins of corneal epithelium. Invest Ophthalmol Vis Sci, 1995. 36(2): p. 355-63.

109. Kucerova, R., et al., Cell surface glycoconjugate abnormalities and corneal epithelial wound healing in the pax6+/- mouse model of aniridia-related keratopathy. Invest Ophthalmol Vis Sci, 2006. 47(12): p. 5276-82.

110. Tuori, A., et al., Lectin binding in normal, scarred, and keratoconus corneas. Cornea, 1998. 17(1): p. 88-98.

111. Gordon, S.R. and J. Marchand, Lectin binding to injured corneal endothelium mimics patterns observed during development. Histochemistry, 1990. 94(5): p. 455-62.

112. Sweatt, A.J., R.M. Degi, and R.M. Davis, Corneal wound-associated glycoconjugates analyzed by lectin histochemistry. Curr Eye Res, 1999. 19(3): p. 212-8.

113. Lawrenson, J.G., A.R. Reid, and G. Allt, Corneal glycoconjugates: an ultrastructural lectin-gold study. Histochem J, 1998. 30(1): p. 51-60.

114. Brandon, D.M., S.K. Nayak, and P.S. Binder, Lectin binding patterns of the human cornea. Comparison of frozen and paraffin sections. Cornea, 1988. 7(4): p. 257-66.

115. Gordon, S.R. and M. Wood, Soybean (Glycine max) agglutinin binds to corneal endothelial cells during wound repair and alters their microfilament pattern. Cell Mol Biol (Noisy-le-grand), 1997. 43(3): p. 329-36.

116. Gordon, S.R., The effects of soybean agglutinin binding on the corneal endothelium and the re-establishment of an intact monolayer following injury--a short review. $\mathrm{J}$ Tissue Viability, 2011. 20(1): p. 20-9.

117. Mencucci, R., et al., Lectin binding in normal, keratoconus and cross-linked human corneas. Acta Histochem, 2011. 113(3): p. 308-16. 